\title{
ADICIONAL DE INSALUBRIDADE: MUDANÇAS COM A REFORMA TRABALHISTA*
}

\author{
Ana Elisa de Vargas Borges** \\ Almiro Eduardo de Almeida***
}

\section{RESUMO}

0 adicional de insalubridade tem como fundamento remoto o princípio da dignidade da pessoa humana, e visa compensar, mediante pagamento de pecúnia, os malefícios que algumas formas de trabalho causam à integridade física do trabalhador. 0 artigo trata sobre a problemática existente na nova legislação trabalhista, em especial, a área que contempla a insalubridade, bem como suas implicações. A proposta é obter uma visão geral e atual sobre o tema, quanto a sua implantação, efetividade, vantagens e desvantagens, por meio de análise crítica sobre a Reforma Trabalhista. 0 objeto de estudo visa, especificamente, analisar os dispositivos que tratam sobre o enquadramento do grau de insalubridade via Convenção Coletiva de Trabalho, a possibilidade de a gestante ou lactante trabalhar em local insalubre e o pagamento de honorários periciais pelo reclamante, mesmo sendo beneficiário da justiça gratuita. Nesse sentido, pode-se vislumbrar a importância do tema proposto, uma vez que se faz

* Trabalho de Conclusão de Curso apresentando ao Curso de Direito do Centro Universitário Metodista - IPA, na área de concentração do Direito do Trabalho como requisito parcial para obtenção do grau de Bacharel em Direito.

** Graduanda do Curso de Bacharelado em Direito do Centro Universitário Metodista - IPA.

*** Orientador do artigo, Mestre em Direitos Sociais e Políticas Públicas pela Universidade de Santa Cruz do Sul - UNISC, Doutor em Direito do Trabalho pela Universidade de São Paulo - USP e Professor do Curso de Bacharelado em Direito do Centro Universitário Metodista - IPA. 
necessário um pensamento crítico e plural para que se atente a todos os lados e necessidades.

Palavras-chave: Adicional de insalubridade. Reforma Trabalhista. Princípios da Proteção e Dignidade da Pessoa Humana.

\section{HAZARD PAY: CHANGES TO LABOR REFORM}

\section{ABSTRACT}

The unhealthy addition to the worker is based on the principle of the dignity of the human person and aims to protect the integrity of the worker. The research deals with the problematic existing in the new labor legislation, especially the area that contemplates the insalubrity, as well as its implications. The proposal its to obtain a current overview on the subject, as to its implantation, effectiveness, advantages and disadvantages through a critical analysis on The Labor Law Reform that has led to changes in the insalubrity. In this sense, we can catch a glimpse of the importance of the proposed theme, once it becomes necessary a critical and pluralistic thought in order to attend to all sides and needs.

Key words: Unhealthy Additional. The Labor Law Reform. Principles of the Protection and Dignity of the Human Person.

\section{INTRODUÇÃO}

0 presente trabalho apresenta questões relacionadas às alterações da Reforma Trabalhista no que diz respeito à insalubridade. A nova lei flexibiliza a proibição de mulheres gestantes ou lactantes de exercerem atividade insalubre e possibilita a negociação do enquadramento do grau de insalubridade. A partir disso, procurou-se pensar sobre como a proteção das mulheres gestantes ou lactantes foi flexibilizada quanto ao exercício de atividade insalubre, bem como sobre a possibilidade de conciliar essa flexibilização com a garantia dos direitos fundamentais da trabalhadora e da criança. Também procuramos analisar formas possíveis de negociar o enquadramento do grau de insalubridade sem ofender os direitos dos trabalhadores.

A flexibilização das relações trabalhistas, especificamente, no Brasil, ganha um caráter conflitivo, em que os empresários argumentam que medidas flexibilizadoras ajudariam a criar no- 
vos postos de trabalho, enquanto os sindicatos representativos dos trabalhadores, em sua grande maioria, argumentam que tais medidas representariam perdas de direitos adquiridos pelos empregados. A Reforma Trabalhista tem a pretensão de impor uma enorme derrota aos trabalhadores, como se eles, em razão de seus direitos, fossem os culpados pela crise econômica.

O Ministério do Trabalho fixou níveis no pagamento de adicional de insalubridade em $10 \%$ do salário percebido quando se trata de insalubridade em grau mínimo, 20\% em grau médio e $40 \%$ em grau máximo. Com a reforma trabalhista, os níveis de adicional permaneceram, entretanto, poderão ter os valores alterados por meio de norma coletiva. A Reforma Trabalhista altera, portanto, as regras para o pagamento do adicional de insalubridade, permitindo que o seu percentual seja estabelecido mediante negociação coletiva. 0 legislador reformista também passou a permitir que empregadas gestantes e lactantes laborem em local insalubre. Em relação à gestante que labora em atividades consideradas insalubres em grau máximo, será inteiramente proibido o seu labor, devendo a trabalhadora ser afastada dessas condições. No entanto, a empregada poderá ser deslocada para atividades em grau médio ou mínimo, tendo em vista que não há vedação para os outros graus de insalubridade. Caso labore em atividades insalubres em grau médio ou mínimo, a gestante ou lactante poderá trabalhar em local insalubre, sendo autorizado o seu afastamento quando apresentar atestado de saúde emitido por médico de sua confiança, recomendando seu afastamento durante a gravidez. Quanto às lactantes, o legislador reformista passa a permitir o labor em qualquer grau de insalubridade, salvo quando apresentar atestado de saúde emitido por médico de confiança da mulher, recomendando o seu afastamento.

0 percurso desta pesquisa partiu da evolução histórica dos direitos trabalhistas. Relatamos as primeiras leis que tratam sobre a saúde do trabalhador e, posteriormente, descrevemos como se 
caracteriza a insalubridade e como se configura sua base de cálculo conforme a legislação trabalhista para, em seguida, tratar dos aspectos de mudança. Sem a pretensão de esgotar o tema, serão apontados os aspectos de mudança do adicional de insalubridade na Reforma Trabalhista, com o intuito de mostrar que, com relação à nova legislação que permite o trabalho insalubre para grávidas e lactantes, a mudança corresponde a um inegável retrocesso no que concerne aos direitos humanos das trabalhadoras. Já com relação à possibilidade do enquadramento do grau de insalubridade via Convenção Coletiva de Trabalho, ao analisarmos o art. 611-A com o 611-B, XVIII, observamos alguns limites na prevalência do negociado sobre o legislado. A negociação coletiva pode ter importante papel no tocante à normatização e à melhoria das condições de trabalho, especialmente, envolvendo o trabalho insalubre, podendo patrões e empregados negociar jornadas reduzidas do trabalho insalubre, estabelecer critérios sobre pausas para evitar fadiga, aumentar os percentuais dos adicionais, além de outras inúmeras questões voltadas à prevenção dos riscos para a saúde dos trabalhadores e à diminuição das doenças e dos acidentes do trabalho, que é o objetivo maior a ser perquirido por todos. Além disso, abordaremos a mudança com relação aos honorários periciais que, agora, passam a ser de responsabilidade do empregado caso não tenha êxito total na ação. Diante do exposto, este trabalho atinge seus objetivos demonstrando de maneira sintetizada, clara e científica as regras e convenções internacionais, bem como os princípios constitucionais mais relevantes a serem respeitados pelo Código de Leis Trabalhista vigente.

\section{EVOLUÇÃO HISTÓRICA}

\subsection{PRIMEIRAS LEIS QUE TRATAM DA SAÚDE DO TRABA-} LHADOR

“A origem histórica do Direito do Trabalho está vinculada ao fenômeno denominado Revolução Industrial” (GOMES; GOTTSACHALK, 2006, p. 1). Nos primórdios das relações de trabalho 
até o início do século XIX, não havia preocupação com a saúde do trabalhador. A partir da Revolução Industrial, surgem novos processos industriais decorrentes da substituição do trabalho manual pelas máquinas, como o tear, máquinas a vapor, máquinas de fiar, etc. Esse sistema produtivo trouxe algumas consequências que afetaram a saúde do trabalhador, consequentemente, doenças e acidentes decorrentes do trabalho causados pela atividade laboral passam a surgir. As péssimas circunstâncias em que exerciam suas atividades e o aumento de enfermidades fez com que esses trabalhadores buscassem melhores condições de trabalho. Em decorrência disso, "O Estado deixa de ser abstencionista e passa a ser intervencionista em matéria de relações de trabalho" (MARTINS, 2009, p. 10). As leis passaram a determinar certos requisitos mínimos que deveriam ser observados pelas empresas. Verificou-se que a ausência de salubridade no local da atividade não só prejudicava o trabalhador, mas também a sociedade em geral, porque, além de diminuir a força de trabalho (ou mão de obra), gerava um grande número de pessoas que necessitavam da assistência social do Estado. "Sob a nova sociedade capitalista, os antigos direitos humanos à vida e à subsistência tinham de ser repensados" (MIRANDA, 1998, p. 3).

Ao verificar-se a necessidade de mudar tal situação, mobilizações políticas foram constituídas, a fim de criar medidas legais que proporcionassem ao trabalhador melhores condições de trabalho. Segundo Miranda (1998, p. 22), foi criada, em 1802, na Inglaterra, a primeira Lei de proteção ao trabalhador, a Lei de Saúde e Moral de Aprendizes, que estabelecia a jornada de trabalho em doze horas diárias, proibia o trabalho noturno e determinava a obrigatoriedade de medidas de melhoramento no ambiente de trabalho, sendo obrigatório um ambiente arejado, limpo e seguro aos funcionários. Em 1834, conforme Nogueira (1979, p. 11), ocorreu, na Inglaterra, a contratação do primeiro Inspetor-Médico de fábricas, medida posteriormente adotada por 
outros países, passando-se a submeter os funcionários a exames médicos admissionais e periódicos, como forma de cuidar e controlar a saúde dos trabalhadores nas fábricas. Em 1862, na França, ocorreu a regulamentação da Segurança e Higiene do Trabalho. Em 1865, na Alemanha, surge a Lei de Indenização Obrigatória dos Trabalhadores, a qual responsabilizou o empregador a pagar ao empregado pelo acidente de trabalho e, em 1873, criou-se a primeira Associação de Higiene e Prevenção de Acidentes, visando prevenir o acidente e amparar o trabalhador acidentado. No início do século XX, começa uma nova fase, denominada constitucionalismo social, em que são inclusos nas constituições preceitos relativos à defesa social da pessoa, de normas de interesse social e da garantia de certos direitos fundamentais, incluindo o Direito do Trabalho. A primeira Constituição a versar sobre direitos trabalhistas foi a do México, em 1917 e, em seguida, a Constituição de Weimar, na Alemanha, em 1919. No mesmo ano, o Tratado de Versalhes criou a Organização Internacional do Trabalho (OIT), que passa a expedir convenções e recomendações sobre temas trabalhistas. Essa fase incorporou princípios como os da dignidade humana e da justiça social, constitucionalizando-os. Sumariadas as primeiras leis que trataram da saúde do trabalhador na Europa, vejamos como a questão evolui em âmbito nacional.

\subsection{EVOLUÇÃO HISTÓRICA DAS LEIS QUE TRATAM DA SAÚ- DE DO TRABALHADOR NO BRASIL}

Somente após 1888, com a abolição do sistema escravista, é que se pode falar sobre o início da histórica do Direito do Trabalho no Brasil. Não significa que não havia relação de trabalho livre antes disso, mas que sua relevância não era tão grande em uma sociedade escravista.

Ressalte-se que não se trata de sustentar que inexistisse no país, antes de 1888, qualquer experiência de relação de emprego, qualquer experiência 
de indústria ou qualquer traço de regras jurídicas que pudessem ter vínculo, ainda que tênue, com a matéria que, futuramente, seria objeto do Direito do Trabalho. Trata-se, apenas, de reconhecer que, nesse período anterior, marcado estruturalmente por uma economia do tipo rural e por relações de produção escravistas, não restava espaço significativo para o florescimento das condições viabilizadoras do ramo jus trabalhista. (DELGADO, 2011, p. 106)

O período entre 1888 e 1930, portanto, representou um primeiro estágio para a questão do trabalho no Brasil. Segundo Moraes (2009, p. 13), em 15 de janeiro de 1919, foi regulamentado o Decreto Legislativo nº 3.724, que compreende a intervenção do Estado nas condições de trabalho no Brasil. Conforme o autor, essa foi a primeira lei de acidentes do trabalho e representou um significativo avanço para o direito brasileiro. Em 1923, o Decreto no 16.027 de 30 de abril de 1923 cria o Conselho Nacional do Trabalho, cuja função é o controle e a supervisão no que diz respeito à Previdência Social. Em 1930, o Decreto no 19.433 de 26 de novembro de 1930 cria o Ministério do Trabalho, Indústria e Comércio, tendo como área de atuação a Higiene e a Segurança do Trabalho. É fundamental ressaltar a importância das conquistas alcançadas pela classe trabalhadora no que se refere à saúde e à proteção ao longo de todos esses anos, bem como à regulamentação de seus direitos enquanto trabalhador e cidadão.

Segundo Nascimento, "fatores internos e externos influíram na formação do direito do trabalho no Brasil” (2006, p. 29). Alguns fatores internos que influenciaram o surgimento do Direito do Trabalho no Brasil foram, por exemplo, o movimento operário e a elevação do número de fábricas e operários. Já entre os fatores externos está a elaboração legislativa de proteção ao trabalhador na Europa e o compromisso internacional assumido pelo Brasil ao participar da Organização Internacional do Trabalho, criada pelo 
Tratado de Versalhes, que propunha a observância das normas trabalhistas. 0 Brasil é um dos membros fundadores da OIT, tendo participado inclusive da primeira Conferência Internacional do Trabalho. Em suas reuniões, denominadas Conferência Internacional do Trabalho (CIT), há formulação e aplicação das normas internacionais do trabalho sob a forma de convenções e recomendações. Em matéria de segurança e saúde do trabalho, há ao menos 21 Convenções dignas de referência, servindo como exemplos as de números 148 (versa sobre a proteção dos trabalhadores contra os riscos profissionais devidos à contaminação do ar, ao ruído e às vibrações no local de trabalho) e 155 (trata, de forma geral, sobre a segurança e saúde dos trabalhadores). A Convenção $148^{1}$ da OIT foi aprovada, no Brasil, pelo Decreto Legislativo $\mathrm{n}^{\circ} 56 / 1981$, do Congresso Nacional, ratificada em 14 de janeiro de 1982, promulgada pelo Decreto Presidencial $n^{\circ}$ 93.413, de 15 de outubro de 1986, e passou a vigorar no plano nacional em 14 de janeiro de 1983. Essa convenção estipula responsabilidade da autoridade competente em estabelecer critérios periodicamente revisados que permitam definir os riscos de exposição à contaminação do ar, ao ruído e às vibrações nos locais de trabalho, fixando limites de exposição, após consulta com pessoas tecnicamente qualificadas designadas pelas organizações interessadas representativas de empregadores e trabalhadores. A convenção também designa responsabilidade dos empregadores, na vigência de riscos profissionais devidos à contaminação do ar, ao ruído ou às vibrações, de eliminar tais riscos, na medida do possível, mediante medidas técnicas ou de organização do trabalho, ou, em último caso, pelo fornecimento de equipamentos de proteção individual. Estabelece a necessidade de controle médico

BRASIL. Convenção no 148 sobre a Proteção dos Trabalhadores Contra os Riscos Profissionais Devidos à Contaminação do ar, ao Ruído e às Vibrações no Local de Trabalho. Disponível em: http://www.planalto.gov.br/ccivil_03/ decreto/1980-1989/D93413.htm. Acesso em: 29 ago. 2018. 
ocupacional dos trabalhadores, sem ônus para os mesmos, e o dever de adotar medidas de promoção da investigação no campo da prevenção e limitação dos riscos devidos à contaminação do ar, ao ruído e às vibrações nos locais de trabalho.

A Convenção $155^{2}$ da OIT, que orienta os signatários a adotarem políticas para prevenção de acidentes e danos à saúde relacionados com a atividade laboral ou que sobrevenham durante o trabalho, foi aprovada pelo parlamento brasileiro por meio do Decreto Legislativo $\mathrm{n}^{0}$ 2, de 1992, e promulgada, por intermédio do então Presidente da República Itamar Franco, pelo Decreto no 1.254, de 29 de setembro de 1994. A Convenção 155 da OIT estabelece o dever de o governo dos países signatários exigir dos empregadores garantia de que seus locais de trabalho, máquinas, equipamentos, operações e processos sejam seguros e não tragam risco à segurança e à saúde dos trabalhadores, além de garantir que agentes e substâncias químicas, físicas ou biológicas sob seu controle não tragam riscos à saúde quando tomadas as cautelas necessárias. Menciona, por fim, a necessidade de as empresas adotarem medidas de promoção da segurança e saúde, por meio da cooperação e comunicação ampla entre trabalhadores e empregadores, bem como do fornecimento de informações e formação adequadas. Segundo Neto (2006, p. 55), a primeira Constituição a tratar sobre Direito do Trabalho foi estabelecida em 1934. Os princípios do Direito do Trabalho foram se direcionando no sentido de amparar o trabalhador, em razão das suas necessidades fundamentais comprometidas pela sua condição econômica de dependência e jurídica de subordinação. Na década de 1930, no Brasil, foi criado, pela Lei no 185 , de 14 de janeiro de $1936^{3}$, o adicional de insalubridade, que tinha por princípio ajudar os

2 BRASIL. Convenção no 155 sobre a Segurança e Saúde dos Trabalhadores e o Meio Ambiente de Trabalho. Disponível em: http://www.planalto.gov.br/ ccivil 03/decreto/1990-1994/D1254.htm. Acesso em: 29 ago. 2018.

3 Câmara Legislativa do Brasil. Lei no 185, de 14 de janeiro de 1936, Institui as comissões de salário mínimo. Disponível em: http://www2.camara.leg. br/legin/fed/lei/1930-1939/lei-185-14-janeiro-1936-398024-publicacaooriginal-1-pl.html. Acesso em: 30 ago. 2018. 
trabalhadores na compra de comida, conforme menciona a economista Nilza Mestieri ${ }^{4}$. Na época, acreditava-se que as pessoas bem alimentadas eram mais resistentes às doenças.

Temos assim, um longo período de pagamento de adicional de insalubridade, ganhando inclusive destaque na Constituição de 1988. Em 1943, foi criada a CLT (Consolidação das Leis do Trabalho), e a higiene do trabalho ganhou um capítulo específico. Em 26 de dezembro de 1968, o Decreto-Lei ${ }^{\circ} 389$ determinou que a caracterização para pagamento de insalubridade fosse feita por médicos e engenheiros, devidamente habilitados em questões de Higiene e Segurança do Trabalho (não existia, como hoje, os engenheiros de segurança e médicos do trabalho). No ano de 1978, surge a Norma Regulamentadora $n^{\circ} 15$ - Atividades e Operações Insalubres, que define o que deve ser considerada atividade insalubre e permanece em vigor até hoje. Visto, brevemente, o panorama histórico no Brasil e no mundo sobre o tratamento à saúde do trabalhador e, de forma específica, sobre o adicional de insalubridade, passemos a examinar os princípios que orientam a matéria.

\section{PRINCÍPIO DA PROTEÇÃO AO TRABALHADOR PRIN- CÍPIO DO NÃO RETROCESSO}

A Constituição Federal estabelece que os direitos fundamentais não são apenas aqueles enumerados no art. 5ํㅜ mas tudo o que estiver de acordo com o regime político do país e com os princípios adotados pela Constituição. Alguns direitos não se acham referidos no capítulo dos direitos e garantias individuais, mas são expressamente mencionados em outras partes. Os direitos dos trabalhadores urbanos e rurais não são, entretanto, ape-

MESTIERI, Nilza. Adicional de periculosidade e adicional de insalubridade. Disponível em: http://nilzamestieri.jusbrasil.com.br/artigos/112358312/ adicional-de-periculosidade-e-adicional-deinsalubridade. Acesso em: 31 ago. 2018. 
nas materialmente fundamentais, conforme revelam a evolução histórica dos direitos fundamentais, a Constituição da República e a Organização Internacional do Trabalho, mas são também formalmente fundamentais, por estarem expressos no Título II da Constituição Federal (Dos direitos e garantias fundamentais). 0 art. $6^{\circ}$ da CF/88 define o trabalho como direito social. 0 art. 1ํㅡㄹ inciso IV, assegura que a República Federativa do Brasil tem como fundamento, entre outros, os valores sociais do trabalho. 0 art. 170 da CF/88 institui que a ordem econômica funda-se na valorização do trabalho, e o art. 193 garante que a ordem social tem como base o primado do trabalho. Os direitos dos trabalhadores, portanto, são elencados na Carta Magna e estão previstos em inúmeras leis. "São direitos dos trabalhadores os enumerados nos incisos do art. 7oㅡ, além de outros que visem à melhoria de sua condição social" (SILVA, 2006, p. 289). À medida que a dignidade da pessoa humana é elevada como fundamento constitucional (art. 7ํㅗ caput da Constituição Federal), surge o chamado "princípio de não retrocesso social", visando à garantia e ao progresso de conquistas alcançadas pela sociedade. Como bem elucidou Canotilho (1998, p. 340), o princípio caracteriza-se pela impossibilidade de redução dos direitos sociais amparados na Constituição, ou que tenham sido positivados em normas infraconstitucionais, garantindo ao cidadão o acúmulo, proteção e perenidade de seu patrimônio jurídico. Nesse sentido, Scarlet (2003, p. 354) afirma que:

A garantia de intangibilidade desse núcleo ou conteúdo essencial de matérias (nominadas de cláusulas pétreas), além de assegurar a identidade do Estado brasileiro e a prevalência dos princípios que fundamentam o regime democrático, especialmente o referido princípio da dignidade da pessoa humana, resguarda também a Carta Constitucional dos 'casuísmos da política e do absolutismo das maiorias parlamentares'. 
O ilustre autor também afirma que:

Negar reconhecimento do princípio da proibição de retrocesso significaria, em última análise, admitir que os órgãos legislativos (assim como o poder público de modo geral), a despeito de estarem inquestionavelmente vinculados aos direitos fundamentais e às normas constitucionais em geral, dispõem do poder de tomar livremente suas decisões mesmo em flagrante desrespeito à vontade expressa do Constituinte. (2004, p. 162)

0 referido princípio, portanto, apresenta-se no ordenamento jurídico pátrio como um mecanismo de defesa dos direitos fundamentais, ante as constantes mudanças legislativas. A finalidade primordial do Direito do Trabalho, portanto, é a melhoria da condição social do trabalhador.

Historicamente, o Direito do Trabalho surgiu como consequência de que a liberdade de contrato entre pessoas com poder e capacidade econômica desiguais conduzia a diferentes formas de exploração. Inclusive as mais abusivas e iníquas. O legislador não pôde mais manter a ficção de igualdade existente entre as partes do contrato de trabalho e inclinou-se para uma compensação dessa desigualdade econômica desfavorável ao trabalhador com uma proteção jurídica a ele favorável. 0 direito do trabalho responde fundamentalmente ao propósito de nivelar desigualdades. (RODRIGUEZ, 1990, p. 85)

Dessa forma, buscando desvencilhar-se das desigualdades econômicas entre empregado e empregador, o legislador imprimiu às normas trabalhistas o dever de refazer, de forma igualitária no campo jurídico, o que se mostra de maneira desigual no mundo dos fatos. 0 Direito do Trabalho veio a compensar a desigualdade 
econômica desfavorável ao trabalhador com uma proteção jurídica favorável, livrando-se da igualdade formal. A partir desse panorama protecionista é que devemos entender a aplicação das normas trabalhistas.

Podemos afirmar que a proteção social aos trabalhadores constitui a raiz vital do Direito do Trabalho, sendo intrínseco a todo o seu sistema jurídico. Segundo Rodriguez (1990, p. 18), existem seis princípios no Direito do Trabalho, entre eles o princípio de proteção. Rodriguez subdividiu o princípio de proteção em três regras: in dubio, pro operario; regra da aplicação da norma mais favorável; e regra da condição mais benéfica (1990, p. 27). Isso significa que, em caso de dúvida na intepretação de uma regra, deverá ser adotada aquela que for mais favorável ao trabalhador. A regra da aplicação da norma mais favorável prevê que a hierarquia das normas jurídicas deve observar a que for mais favorável ao trabalhador, e a regra da condição mais benéfica considera que devem ser mantidas as condições normativas de trabalho que forem mais benéficas ao trabalhador, como uma espécie de direito adquirido. Nas palavras de Rodriguez: "a regra da condição mais benéfica pressupõe a existência de uma situação concreta, anteriormente reconhecida, e determina que ela deve ser respeitada, na medida em que seja mais favorável ao trabalhador que a nova norma aplicável" (1990, p. 28). Como podemos ver, a regra da condição mais benéfica pressupõe uma regra já aplicada ao caso concreto, e determina que deva ser respeitada. Delgado afirma que tanto a elaboração quanto a hierarquia das normas jurídicas e a interpretação devem ser favoráveis e benéficas ao trabalhador:

Também conhecido como princípio tutelar, o princípio da proteção exerce influência em todos os segmentos do Direito do Trabalho. Tanto as regras, quanto os outros princípios, e as presunções desse ramo jurídico objetivam proteger e tutelar 
os interesses dos empregados. Ausente essa ideia protetivo-retificadora, o Direito do Trabalho perde sua essência e deixa de existir. (2011, p. 198)

Esses princípios são fontes basilares do Direito do Trabalho, os meios hábeis de apreensão e de efetividade, pois eles é que deveriam dar ensejo às leis trabalhistas. São, portanto, indispensáveis para a concretização da legislação trabalhista. Após essa abordagem sobre as bases do direito do trabalho que norteiam sua aplicação, descreveremos como se caracteriza a insalubridade.

\section{A INSALUBRIDADE NA LEGISLAÇÃO E A REFORMA TRABALHISTA}

\subsection{CARACTERIZACÃO}

O empregado que estiver exposto, de modo contínuo ou intermitente, a agentes insalubres faz jus ao adicional de insalubridade, como uma forma de compensar o trabalhador pelo trabalho prestado em condições que possibilitem a atuação de agentes nocivos à saúde. Como está descrito na CLT Comentada pelos Juízes do Trabalho da $4^{\mathrm{a}}$ Região:

Existe insalubridade quando o empregado sofre agressão de agentes físicos ou químicos acima dos níveis de tolerância fixados pelo MTE, em razão da natureza e da intensidade do agente e do tempo de exposição aos seus efeitos; ou, ainda, de agentes biológicos. A insalubridade tem as características de agir de forma agressiva, cumulativa e paulatina. Ocorre a eliminação ou neutralização da insalubridade com a) adoção de medidas que conservem o ambiente de trabalho dentro dos limites de tolerância; b) utilização de equipamento de proteção que diminua a intensidade do agente agressivo a limites de tolerância; c) remoção do funcionário do setor com condição insalubre; d) reclassificação ou descaracterização, feita por autoridade competente. 
Não havendo eliminação ou neutralização, surge direito ao pagamento do adicional de insalubridade em grau mínimo, médio ou máximo. [...] A NR-15 da Portaria n.3.214/78 do MTE dispõe sobre as atividades e operações insalubres, consideradas como tais aquelas que se desenvolvem acima dos limites de tolerância previstos nos Anexos 1, 2, 3, 5, 11 e 12, nas atividades mencionadas nos Anexos 6, 13 e 14 e as comprovadas por laudo de inspeção no local de trabalho para aquelas listadas nos Anexos 7, 8, 9 e 10. (SOUZA, 2017, p. 141)

0 direito à percepção do adicional de insalubridade está condicionado, portanto, ao preenchimento de quatro requisitos: realização de perícia por profissional; previsão do agente insalubre na Norma Regulamentadora no 15, da Portaria nํ 3.214/1978 do Ministério do Trabalho e Emprego; extrapolação dos limites de tolerância elencados pela mesma Norma; e ausência de medidas que elidam a insalubridade como, por exemplo, a adoção de Equipamentos de Segurança Individual - EPIs. A Norma Regulamentadora no 15, criada pelo Ministério do Trabalho e Emprego (MTE), define em seus anexos os agentes insalubres, trata sobre os parâmetros técnicos referentes à caracterização e à classificação das atividades insalubres, estipula limites de tolerância e o adicional devido para cada caso. Em síntese, apresentam-se os agentes que acarretam o dever de pagamento do adicional de insalubridade, uma vez que, se existentes no ambiente de trabalho, tornam-no insalubre. A Tabela 1 apresenta os agentes insalubres,

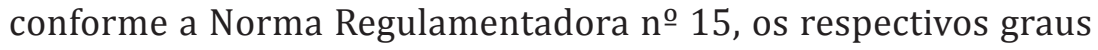
de insalubridade e o quantum do adicional de insalubridade correspondente. 


\begin{tabular}{|c|c|c|c|}
\hline $\begin{array}{c}\text { Anexo } \\
\text { da } \\
\text { NR-15 }\end{array}$ & Agentes insalubres & $\begin{array}{c}\text { Grau de } \\
\text { insalubridade }\end{array}$ & $\begin{array}{l}\text { Adicional } \\
\text { respectivo } \\
\text { devido }\end{array}$ \\
\hline 1 & $\begin{array}{l}\text { Níveis de ruído contínuo ou } \\
\text { intermitente superiores à tolerância } \\
\text { estabelecida }\end{array}$ & Médio & $20 \%$ \\
\hline 2 & $\begin{array}{l}\text { Níveis de ruído de impacto } \\
\text { superiores aos limites de tolerância } \\
\text { estabelecidos }\end{array}$ & Médio & $20 \%$ \\
\hline 3 & $\begin{array}{l}\text { Exposição ao calor radiante com } \\
\text { valores de IBUTG superiores aos } \\
\text { limites de tolerância estabelecidos }\end{array}$ & Médio & $20 \%$ \\
\hline 4 & Iluminamento (revogado) & Máximo & $40 \%$ \\
\hline 5 & $\begin{array}{l}\text { Níveis de radiação ionizante } \\
\text { (raios X, Alfa, Beta e Gama) com } \\
\text { radioatividade superior aos limites } \\
\text { de tolerância estabelecidos }\end{array}$ & Máximo & $40 \%$ \\
\hline 6 & $\begin{array}{l}\text { Pressões hiperbáricas (ar } \\
\text { comprimido e atividades de } \\
\text { mergulho) }\end{array}$ & Máximo & $40 \%$ \\
\hline 7 & $\begin{array}{l}\text { Radiações não ionizantes (micro- } \\
\text { ondas, ultravioleta e laser) }\end{array}$ & Médio & $20 \%$ \\
\hline 8 & $\begin{array}{l}\text { Níveis de vibração superiores aos } \\
\text { limites de tolerância estabelecidos }\end{array}$ & Médio & $20 \%$ \\
\hline 9 & Frio & Médio & $20 \%$ \\
\hline 10 & Umidade & Médio & \\
\hline 11 & $\begin{array}{l}\text { Níveis de agentes químicos cujas } \\
\text { concentrações superam os limites } \\
\text { de tolerância estabelecidos }\end{array}$ & $\begin{array}{l}\text { Máximo } \\
\text { Médio } \\
\text { Mínimo }\end{array}$ & $\begin{array}{l}40 \% \\
20 \% \\
10 \% \\
\end{array}$ \\
\hline 12 & $\begin{array}{l}\text { Níveis de poeira mineral acima dos } \\
\text { limites de tolerância estabelecidos }\end{array}$ & Máximo & $40 \%$ \\
\hline 13 & $\begin{array}{l}\text { Agentes químicos sem fixação de } \\
\text { limites de tolerância e considerados } \\
\text { insalubres em função de inspeção } \\
\text { qualitativa realizada no local de } \\
\text { trabalho }\end{array}$ & $\begin{array}{l}\text { Máximo } \\
\text { Médio } \\
\text { Mínimo }\end{array}$ & $\begin{array}{l}40 \% \\
20 \% \\
10 \%\end{array}$ \\
\hline 14 & $\begin{array}{l}\text { Agentes biológicos (microrganismos } \\
\text { em geral) }\end{array}$ & $\begin{array}{l}\text { Máximo } \\
\text { Médio }\end{array}$ & $\begin{array}{l}40 \% \\
20 \%\end{array}$ \\
\hline
\end{tabular}

Fonte: Meirelles (2011, p. 67). 
Não é, portanto, qualquer trabalho nocivo que gera o direito ao adicional em questão, devendo haver previsão expressa nas normativas do Ministério do Trabalho. Considerando que diferentes agentes nocivos podem ensejar o direito a diferentes percentuais de adicionais, variáveis, inclusive, de acordo com o grau de nocividade de cada agente, é necessário verificar a possibilidade, ou não, de cumulação de adicionais quando o trabalhador estiver sujeito a mais de um agente nocivo.

\section{2 (IM)POSSIBLIDADE DE CUMULAÇÃO DE DOIS OU MAIS ADICIONAIS DE INSALUBRIDADE}

De acordo com a Norma Regulamentadora $n^{\circ} 15$, item 15.3, havendo "incidência de mais de um fator de insalubridade, será apenas considerado o de grau mais elevado, para efeito de acréscimo salarial, sendo vedada a percepção cumulativa".

Como já visto, o adicional de insalubridade é devido quando o empregado realiza atividades que, por sua natureza, condições ou métodos de trabalho, ameaçam sua saúde, como contato com agentes químicos, umidade, excesso de ruídos, entre outros. Essa possível proibição de recebimento concomitante dos adicionais de insalubridade demonstra um cenário problemático. Barros (2011, p. 623) critica fortemente esse posicionamento ao argumentar que, se o adicional visa ressarcir a nocividade do trabalho executado e se as nocividades são múltiplas, os adicionais também deveriam ser. Ademais, não há obstáculo criado pela lei nesse aspecto. "Entendemos que, se as condições de trabalho do empregado são duplamente gravosas, é cabível o pagamento dos dois adicionais, pois houve exposição a dois agentes insalubres diferentes, que podem ocasionar prejuízos a diversos órgãos do corpo humano". Ademais, como bem coloca a mesma autora, o teor da Norma Regulamentadora $n^{\circ} 15$, no sentido de considerar apenas o fator de insalubridade de maior grau no caso de incidência de mais de um agente insalubre, extrapola os limites da 
própria lei, que não proíbe a cumulação de mais de um adicional de insalubridade. Ao se permitir tal dispositivo, o empregador poderá perder o estímulo de eliminar outros agentes agressivos, porquanto, a Portaria só o onera com o pagamento de um deles. Nesse aspecto, a Norma Regulamentadora $\mathrm{n}^{\circ} 15$ conflita com o art. 7ํㅡ, inciso XXII, da Constituição, que reconhece como direito dos trabalhadores a redução dos riscos inerentes ao trabalho por meio de normas de saúde, higiene e segurança.

Imagine-se a seguinte situação: um trabalhador rural, especificamente, um cortador de cana-de-açúcar, que trabalha em exposição excessiva ao calor e em constante contato com agrotóxicos. Não poderia fazer jus, nesse caso, a dois adicionais de insalubridade? 0 argumento trazido pela doutrina, favorável à cumulação dos adicionais de insalubridade, portanto, seria de que os fatos geradores de cada adicional são diferentes, não podendo o pagamento de um adicional cessar o pagamento do outro. Vejamos a afirmação do jurista e professor Jorge Luiz Souto Maior (2006, p. 14):

Acumulação de adicionais: como o princípio é o da proteção do ser humano, consubstanciado, por exemplo, na diminuição dos riscos inerentes ao trabalho, não há o menor sentido continuar-se dizendo que o pagamento de um adicional 'quita' a obrigação quanto ao pagamento de outro adicional.

A possibilidade de cumulação de adicionais de insalubridade, portanto, é juridicamente cabível. Se, ao exercer a direção de sua atividade, o empregador sujeita o trabalhador a mais de uma circunstância insalubre, é justo que pague os adicionais correspondentes às situações efetivamente verificadas no ambiente de trabalho, sob pena de ofensa, inclusive, ao princípio da isonomia. A Constituição Federal tem como fundamento a dignidade da pessoa humana (arts. 1ํ, inciso III, e 170) e não restringe a cumulação de 
adicionais, porque dispõe expressamente sobre a proteção à saúde do trabalhador (arts. 7ํ, inciso XXII, 196, 197 e 200, inciso VIII, da CF/88). Nesse sentido, afirma Almeida (2016, p. 14):

[...] entendendo-se que o dispositivo em questão efetivamente afasta o direito de o trabalhador perceber os adicionais de forma cumulativa, mesmo trabalhando em ambiente com mais de um agente nocivo, ter-se-á, necessariamente, de concluir pela sua inconstitucionalidade. Isso porque, tratando-se de inquestionável direito fundamental, cabe à legislação infraconstitucional apenas regulamentá-lo, sendo inadmissível que simplesmente o elimine. Ao prever expressamente o direito aos três adicionais, a Constituição não os exclui reciprocamente ou condiciona o recebimento de um ao não recebimento de outro.

Com base em fundamento constitucional, a doutrina minoritária se posiciona favoravelmente à percepção cumulativa dos adicionais, entendendo a possibilidade de terem naturezas distintas, visto que o adicional de insalubridade terá lugar quando da ocorrência de riscos à saúde do trabalhador. Não é razoável, portanto, entender que o trabalhador deva receber apenas um adicional quando as causas que justificam o seu pagamento são diversas. Portanto, comprovado por meio de laudo técnico que o trabalhador no exercício de suas funções esteve efetivamente exposto a mais de um agente insalubre, o percebimento cumulativo dos adicionais de insalubridade é a medida que se impõe, atingindo-se, assim, o fim a que se destina a norma trabalhista referente ao adicional de insalubridade. Além disso, duas convenções da Organização Internacional do Trabalho garantem a acumulação de adicionais de insalubridade. A Convenção $\mathrm{n}$ o 148 da OIT $^{5}$, ratificada pelo Decreto no 93.413/1986, apresenta

5 Disponível em: http://www.planalto.gov.br/ccivil_03/decreto/1980-1989/ D93413.htm. Acesso em: 09 nov. 2018. 
recomendações a respeito da insalubridade de meio ambiente de trabalho e consagra a proteção dos trabalhadores contra os riscos profissionais devidos à contaminação do ar, ao ruído e às vibrações no local de trabalho. A referida convenção, em seu art. 8o, Anexo 3, aduz os critérios e limites de exposição da seguinte maneira:

Os critérios e os limites de exposição deverão ser fixados, completados e revistos com regularidade, à luz dos conhecimentos e dos novos dados nacionais e internacionais, tendo em conta, na medida do possível, todos os aumentos dos riscos profissionais resultantes da exposição simultânea a vários fatores nocivos no local de trabalho.

Pelo exposto, as medidas de prevenção e proteção ao trabalhador devem estar sempre em regularidade, buscando assegurar um local seguro que não venha a prejudicar o trabalhador. Já a Convenção da OIT nำ $155^{6}$, ratificada pelo Brasil por meio do Decreto $\mathrm{n}$ 0 1.254/1994, trata, essencialmente, a respeito da política nacional sobre a segurança e a saúde dos trabalhadores e determina que sejam levados em conta os riscos para a saúde decorrentes da exposição a diversas substâncias ou agentes que possam afetar a vida do trabalhador. A referida Convenção prevê em seu art. 11, alínea b:

A determinação das operações e processos que estarão proibidos, limitados ou sujeitos à autorização ou ao controle da autoridade ou autoridades competentes, bem como a determinação das substâncias e agente as quais a exposição no trabalho estará proibida, limitada ou sujeita à autorização ou ao controle da autoridade ou das autoridades competentes; deverão levar-se em consideração

6 Disponível em: http://www.planalto.gov.br/ccivil_03/decreto/1990-1994/ d1254.htm. Acesso em: 09 nov. 2018. 
os riscos para a saúde causados pela exposição simultânea a várias substâncias ou agentes.

A referida Convenção prevê a possibilidade de exposição simultânea a várias substâncias ou agentes, e define que os trabalhos prestados em condições insalubres, necessariamente, não devem existir, mas, caso existam, submetem-se ao controle da autoridade competente. Também, o art. 21 da referida norma internacional preceitua que "as medidas de segurança e higiene do trabalho não deverão implicar nenhum ônus financeiro para o trabalhador". Diante disso, percebe-se que os dispositivos da Convenção n 155 não estão de acordo com a vedação contida na Norma Regulamentadora 15 , ao coibir a possibilidade de cumulações dos adicionais de insalubridade.

O TST já vem entendendo a possibilidade de acumulação de dois adicionais de nocividade no caso de trabalho insalubre e perigoso (RR-773-47.2012.5.04.001) ${ }^{7}$ sob o argumento de que a previsão contida no art. 193, § $2^{\circ}$, da CLT não foi recepcionada pela Constituição Federal de 1988 que, em seu art. 7ํㅡ, inciso XXIII, garantiu, de forma plena, o direito ao recebimento dos adicionais de penosidade, insalubridade e periculosidade, sem qualquer ressalva no que tange à cumulação, ainda que tenha remetido sua regulação à lei ordinária. A possibilidade da cumulação justifica-se em virtude de os fatos geradores dos direitos serem diversos. Por razões análogas, entendemos ser plenamente possível a cumulação de dois adicionais de insalubridade quando o trabalhador estiver exposto a agentes distintos.

A Norma Regulamentadora $n^{\circ} 15$ também é responsável por determinar os níveis de tolerância de insalubridade, ou seja: a

7 TST.RECURSO DE REVISTA: RR 7734720125040015, Relator: Ministro Cláudio Brandão. 22/04/2015.JusBrasil, 2015. Disponível em: https:// tst.jusbrasil.com.br/jurisprudencia/185396466/recurso-de-revista-rr-7734720125040015/inteiro-teor-185396489?ref=juris-tabs. Acesso em: 27 set. 2018 . 
concentração máxima ou o limite de tempo em que o trabalhador pode ficar exposto à determinado agente insalubre. Os limites estabelecidos por essa norma são baseados em estudos que especificam os níveis de agentes agressivos que são prejudiciais à saúde. Conforme o conceito da Norma Regulamentadora $\mathrm{n}^{\circ}$ 15, item 15.1.5: “Entende-se por 'Limite de Tolerância', para fins dessa Norma, a concentração ou intensidade, máxima ou mínima, relacionada com a natureza e o tempo de exposição ao agente, que não causará danos à saúde do trabalhador durante sua vida laboral". Em outras palavras, o limite de tolerância é um valor em que, abaixo dele, o trabalhador não sofrerá danos à sua saúde.

Considerando que as normas de saúde, higiene e segurança têm por objetivo a redução dos riscos inerentes ao trabalho, cabe aos empregadores buscar, em primeiro lugar, a eliminação dos efeitos dos agentes insalubres e, na impossibilidade, a neutralização ou redução desses efeitos a limites legalmente aceitáveis. Há duas hipóteses legalmente previstas acerca da possibilidade de eliminação ou neutralização da insalubridade no art. 191 da CLT, que o empregador deverá adotar, visando à proteção da saúde do trabalhador. A eliminação ou a neutralização da insalubridade, nos termos do art. 191 da CLT, ocorre mediante medidas de caráter coletivo (adoção de medidas de ordem geral que conservem o ambiente de trabalho dentro dos limites de tolerância) e medidas de caráter individual (utilização de Equipamentos de Proteção Individual - EPIs - ao trabalhador, que diminuam a intensidade do agente agressivo a limites de tolerância).

Nesse ínterim, merece destaque o entendimento externado pelas Súmulas 80 e 248 do TST:

Súmula no 80 do TST - INSALUBRIDADE. A eliminação da insalubridade mediante fornecimento de aparelhos protetores aprovados pelo órgão competente do Poder Executivo exclui a percepção do respectivo adicional. (BRASIL, 2003) 
Súmula nº 248 do TST - ADICIONAL DE INSALUBRIDADE. DIREITO ADQUIRIDO. A reclassificação ou a descaracterização da insalubridade, por ato da autoridade competente, repercute na satisfação do respectivo adicional, sem ofensa à direito adquirido ou ao princípio da irredutibilidade salarial. (BRASIL, 2003)

A eliminação ou a neutralização da insalubridade, portanto, determinará a cessação do pagamento do respectivo adicional. Contudo, o fornecimento de Equipamentos de Proteção Individual nem sempre é suficiente para eliminar a insalubridade, devendo o empregador adotar medidas que diminuam ou eliminem os efeitos nocivos do agente insalubre.

Súmula no 289 do TST - INSALUBRIDADE. ADICIONAL. FORNECIMENTO DO APARELHO DE PROTEÇÃO. EFEITO. O simples fornecimento do aparelho de proteção pelo empregador não o exime do pagamento do adicional de insalubridade. Cabe-lhe tomar as medidas que conduzam a diminuição ou eliminação da nocividade, entre as quais as relativas ao uso efetivo do equipamento pelo empregado.

Ou seja, além de fornecer aparelhos de proteção ao trabalhador, é preciso manter uma fiscalização e um histórico completo das ações dos trabalhadores para provar o correto uso dos equipamentos e, assim, eliminar o adicional de insalubridade.

INSALUBRIDADE. FRIGORÍFICO. AGENTES BIOLÓGICOS. EQUIPAMENTOS DE PROTEÇÃO. Enquadra-se como insalubre em grau máximo a atividade que sujeita o trabalhador ao risco de contato com germes patogênicos, independentemente do uso de equipamentos de proteção individual. As luvas não servem para afastar a nocividade da exposição a agentes biológicos, pois servem como veículo de proliferação de agentes infecciosos. A avaliação é 
qualitativa, importando apenas o risco inerente à atividade, o qual se caracteriza pela mera possibilidade de presença de animais infectados, já que um breve e único contato é suficiente para ensejar a contaminação do trabalhador. Adicional de insalubridade em grau máximo devido. Improvido o recurso da reclamada. (Rio Grande do Sul, TRT. RO: 0020746-24.2015.5.04.0551, Data de Julgamento: $07 / 10 / 2016)$.

AGRAVO DE INSTRUMENTO. RECURSO DE REVISTA. PROCESSO ANTERIOR ÀS LEIS 13.015/2014 $\mathrm{e}$ 13.467/2017. TRABALHO EM CONDIÇÕES INSALUBRES NÃO NEUTRALIZADAS PELO FORNECIMENTO SUCIFIENTE E ADEQUADO À PROTEÇÃO DA SAÚDE DO EMPREGADO. SÚMULA 289 DO TST. SÚMULA 126/TST.

No caso concreto, segundo o TRT, em consonância com as informações trazidas pelo perito, o número de pares de luvas fornecidos ao obreiro foi insuficiente, não protegendo o Reclamante do contato com o agente nocivo à sua saúde. Ademais, consta, no acórdão regional, que o Reclamado não produziu provas que infirmassem as informações contidas no laudo técnico. Assim, o Tribunal Regional entendeu aplicável ao caso a Súmula 289 do TST, que dispõe: "O simples fornecimento do aparelho de proteção pelo empregador não o exime do pagamento do adicional de insalubridade. Cabe-lhe tomar as medidas que conduzam a diminuição ou eliminação da nocividade, entre as quais as relativas ao uso efetivo do equipamento pelo empregado". Limitando-se o recurso à questão afeta ao fornecimento dos equipamentos de proteção individual, questão fática insuscetível de revisão por esta Corte (Súmula 126/TST), deve ser desprovido o apelo. Agravo de instrumento desprovido.

Processo: AIRR - 1067-60.2015.5.14.0 001 Data de Julgamento: 18/04/2018, Relator Ministro: 
Mauricio Godinho Delgado, 3aㅡ Turma, Data de Publicação: DEJT 27/04/2018.

Conforme dispõe a Norma Regulamentadora ${ }^{\circ}$ 6, a empresa é obrigada a fornecer aos empregados, gratuitamente, EPI adequado ao risco, em perfeito estado de conservação e funcionamento, sempre que as medidas de ordem geral não oferecerem completa proteção contra os riscos de doenças profissionais e do trabalho, enquanto as medidas de proteção coletiva estiverem sendo implantadas e para atender a situações de emergência. Equipamento de Proteção Individual é entendido, portanto, segundo a norma, como todo o dispositivo ou produto, de caráter individual, utilizado pelo empregado, com a finalidade de protegê-lo e de minimizar os riscos e perigos suscetíveis de ameaça à sua integridade física e psíquica. Conforme os julgados acima, por exemplo, o fornecimento de equipamentos de proteção foi insuficiente, não protegendo os reclamantes do contato com agentes nocivos à saúde. É importante ressaltar, portanto, que não basta fornecer os equipamentos de proteção, ou seja, o dever da empresa não acaba com o simples fornecimento, já que a fiscalização, orientação, higienização e manutenção periódica também são de sua responsabilidade. Não tendo sido totalmente elidido o adicional, a empresa deverá pagar o percentual correspondente ao agente insalubre verificado no trabalho. Como visto, esse percentual varia conforme a gravidade da nocividade do agente em graus mínimo (10\%), médio (20\%) e máximo (40\%). Passemos a analisar sobre qual base de cálculo deve ser aplicado o adicional.

\subsection{BASE DE CÁLCULO DO ADICIONAL DE INSALUBRIDADE}

Há algum tempo, travou-se grande controvérsia sobre qual seria a base de cálculo do adicional de insalubridade. A controvérsia sobre a matéria reside no fato de que, até o advento da Constituição Federal de 1988, era possível, ao Poder Legislativo, 
aprovar leis que vinculassem determinado direito ao salário mínimo vigente no País. Essa afirmação é possível justamente pelo fato de o adicional de insalubridade estar inserido na Consolidação das Leis do Trabalho, tomando-se como base de cálculo o salário mínimo. A Consolidação das Leis do Trabalho afirma, no art. 192, que a base de cálculo do adicional de insalubridade é o salário mínimo. A Carta Republicana de 1988, por sua vez, veda, no art. 7ํㅜ inciso IV, a vinculação do salário mínimo para qualquer fim. Por envolver matéria constitucional, o litígio chegou ao Supremo Tribunal Federal em sede de controle difuso de constitucionalidade. Inicialmente, portanto, utilizava-se o salário mínimo como base do cálculo, conforme dispõe o art. 192 da Consolidação das Leis do Trabalho. Contudo, em sede de Recurso Extraordinário, o Supremo Tribunal Federal julgou inconstitucional o uso do salário mínimo como base de cálculo de qualquer vantagem a servidor público ou empregado, o que inclui o adicional de insalubridade.

O Supremo Tribunal Federal resolveu aprovar a Súmula Vinculante no 4 nos seguintes termos: "Salvo os casos previstos na Constituição Federal, o salário mínimo não pode ser usado como indexador de base de cálculo de vantagem de servidor público ou de empregado, nem ser substituído por decisão judicial". Com a edição da Súmula Vinculante no ${ }^{4}$, que veda a utilização do salário mínimo como indexador, o TST cancelou a Súmula $17^{8}$ e alterou a redação da Súmula 228, além de definir o salário contratual do trabalhador para sobre ele ser calculado o adicional de insalubridade. A Confederação Nacional da Indústria distribuiu Reclamação Constitucional ao Supremo Tribunal Federal que, liminarmente, suspendeu os efeitos da

8 Súmula no 17 do TST: "O adicional de insalubridade devido à empregado que, por força de lei, convenção coletiva ou sentença normativa, percebe salário profissional será sobre este calculado." Disponível em: http://www3.tst.jus. br/jurisprudencia/Sumulas_com_indice/Sumulas_Ind_1_50.html\#SUM-17. Acesso em: 10 set. 2018. 
nova redação da Súmula $228^{9}$ do Tribunal Superior do Trabalho. A partir disso, entende-se que o adicional de insalubridade, até que nova base seja instituída, continua sendo calculado sobre o salário mínimo. Entendido como se caracteriza a insalubridade, demonstrado a possibilidade de cumulação de dois ou mais adicionais de insalubridade e esclarecido como funciona a sua base de cálculo, passaremos a traçar as alterações trazidas com a Reforma Trabalhista.

\section{ALTERAÇÕES TRAZIDAS PELA REFORMA TRABALHISTA E SUA CRÍTICA}

Com o passar do tempo, muitas demandas, sob vários aspectos, sofreram modificações: relações, necessidades, interesses, perspectivas, etc. Toda mudança provoca estranhamentos entre os interesses e seus interessados. Há sempre dois lados de uma mesma moeda. As alterações na Consolidação das Leis do Trabalho (CLT), realizadas pela Lei no $13.467 / 2017$, tiveram por objetivo combater o desemprego e a crise econômica no país. A Reforma Trabalhista de 2017 trouxe uma mudança significativa com relação à insalubridade. 0 Projeto de Lei foi proposto e apresentado pelo Presidente da República, Michel Temer, em 23 de dezembro de 2016, na Câmara dos Deputados, e aprovado em 26 de abril de 2017, com 296 votos favoráveis por 177 votos contrários. No Senado Federal, foi aprovado, em 11 de julho de 2017, com 50 votos favoráveis por 26 votos contrários. Foi, então, sancionado pelo Presidente da República, Michel Temer, em 13 de julho de 2017, sem vetos. A lei passou a valer no país a partir de 11 de

9 Súmula no 228 do TST: "A partir de 09 de maio de 2008, data da publicação da Súmula Vinculante no 4 do Supremo Tribunal Federal, o adicional de insalubridade será calculado sobre o salário básico, salvo critério mais vantajoso fixado em instrumento coletivo. Disponível em: http://www3. tst.jus.br/jurisprudencia/Sumulas_com_indice/Sumulas_Ind_201_250. html\#SUM-228. Acesso em: 10 set. 2018. 
novembro de 2017 (120 dias após a publicação, em 14 de julho de 2017, no Diário Oficial) ${ }^{10}$.

O Projeto de Lei não foi objeto de um amplo debate social com a participação de todos os setores interessados. Conforme Nota Técnica no 7 do Ministério Público do Trabalho, entre a divulgação do relatório e a aprovação do Projeto de Lei na Câmara, houve meras 26 horas de debate parlamentar. ${ }^{11}$ A nota informa que a reforma da legislação trabalhista foi aprovada sem permitir a completa compreensão e a participação popular, provocando um déficit democrático que compromete a legitimidade da nova legislação, em muitos pontos, claramente prejudicial aos trabalhadores. A Reforma, portanto, foi aprovada sem qualquer debate ou discussão prévia com a comunidade jurídica e a sociedade em geral. A maior mudança que a CLT já sofreu, foi feita às pressas. Por se tratar de um tema complexo, a Reforma Trabalhista deveria ter passado por um debate mais amplo.

A Reforma, realizada sem a profundidade necessária, sem uma análise do impacto que cada uma das alterações na CLT poderia provocar e com ausência de um debate amplo com a sociedade, acabou gerando insegurança jurídica. Como se sabe, a segurança jurídica nas relações contratuais é muito importante para as empresas e para os trabalhadores. Com o advento da Lei $\mathrm{n}^{\circ} 13.467 / 2017$, houve significativa modificação na legislação que regula o direito laboral brasileiro. Paradigmas foram substituídos, regras dogmáticas alteradas de forma abrupta, ou seja, o processo legislativo tramitou em caráter de urgência, e a realidade do direito do trabalho brasileiro deu um salto para um novo mundo. Após a sanção presidencial, a sociedade começou a

10 Notícia disponível em: http://www2.planalto.gov.br/acompanheplanalto/ noticias/2017/07/dialogo-e-responsabilidade-provocam-avanco-extraordinariona-legislacao. Acesso em: 12 out. 2018.

11 Notícia Disponível em: http://portal.mpt.mp.br/wps/wcm/connect/ portal_mpt/6e18cf0c-941b-437e-8557-f 7554daae5b4/notatecnica 07. pdf?MOD=AJPERES\&CVID=lNvhrzL. Acesso em: 12 out. 2018. 
tomar consciência da lei e de seus impactos nas relações sociais, novos mecanismos de acesso ao Judiciário, novas figuras contratuais de trabalho, restrições e precarizações de direitos, deixando claro que as referidas mudanças revelam a força ideológica do agrupamento político e interesses prevalecentes do capital.

Conforme descrito na Reforma Trabalhista Comentada por Juízes do Trabalho da 12ª Região, foram 106 alterações em artigos da CLT promovidas pela Reforma Trabalhista. Essas várias mudanças afetam o dia a dia do empregado e empregador. Conforme a análise dos juízes, a Lei $\mathrm{n}^{\circ} 13.467 / 2017$ trouxe dispositivos favoráveis aos trabalhadores em apenas 3,77\% de suas alterações, enquanto 65,09\% do texto beneficia os empregadores e empresas (LISBÔA; MUNHOZ, 2018, p. 26).

Para Cassar (2014, p. 83), a flexibilização do direito do trabalho da maneira que é proposta no país encaixa-se em uma visão negativa, pois faz com que sejam estipuladas novas formas de condições de trabalho, buscando uma adaptação do ordenamento legal frente aos avanços empresariais e profissionais, fazendo com que surja a possibilidade de serem introduzidas no ordenamento vigente normas gerais que estão abaixo daquilo que é aceitável para que o trabalhador mantenha sua dignidade. Outro fator apontado pela autora é que, com a flexibilização, o Estado acaba estabelecendo um limite máximo e mínimo para que as partes da relação de trabalho negociem, o que faz com que a parte hipossuficiente, o trabalhador, busque abrir mão de seus direitos, submetendo-se a condições de trabalho que antes não faria, com o único propósito de buscar a dignidade por intermédio do trabalho. Essa busca por trabalho, sob o âmbito da mudança na legislação, dá-se em um cenário no qual o trabalhador ou aceita a flexibilização, seja qual ela for, ou simplesmente não conseguirá oportunidades de trabalho.

Süssekind (2004, p. 28) defende a possibilidade de que aconteçam flexibilizações no ordenamento justrabalhista, mas que, 
para alcançarmos um modelo de regulamentação condizente com o modelo de sociedade em que nos inserimos, as interferências do Estado nas relações de trabalho dependerão tanto do sistema econômico adotado pelo regime jurídico-político, quanto da possibilidade de os sindicatos poderem estipular as condições de trabalho adequadas por intermédio da negociação coletiva.

Ao encontro do pensamento desses autores, Pastore (1995, p. 59) vê a flexibilização da estrutura da lei trabalhista como a saída para que as relações sociais e a economia sejam impulsionadas, uma vez que, para ele, a legislação trabalhista é a principal causadora do grande número de informalidade, e modificá-la consistiria em uma maneira de inserir o país de forma competitiva no mercado mundial. No mesmo sentido, Braghini (2017, p. 7) entende que a contextualização atual do Direito do Trabalho faz com que seja necessária uma nova regulamentação, visando a uma harmonia mais eficiente da relação de poder estabelecida entre capital e trabalho, visto que o cenário nacional apresenta uma crescente informalidade no mercado de trabalho, já que não está sendo possível evitar os altos níveis de desemprego estrutural. Ademais, lembra o autor de que há um constante movimento tecnológico, o que faz com que os modelos de emprego tradicionais sofram reflexos negativos caso não sejam realinhados à realidade contemporânea.

Entretanto, pondera o autor, ainda que seja necessária uma flexibilização dos direitos trabalhistas, não se deve descuidar da ideologia socioprotetiva, em que se baseia a legislação trabalhista brasileira e que foi construída historicamente, devendo a flexibilização ser promovida de forma que seja possível assegurar a efetividade dos direitos fundamentais dos trabalhadores. Em outras palavras, a Reforma Trabalhista deve reafirmar os valores contidos no corpo da Constituição Federal de 1988, preservando a ordem econômica e o Estado social, resguardando as condições mínimas de trabalho digno e deixando de lado o pensamento 
de que o desenvolvimento econômico só será possível caso seja freado o progresso social do trabalhador.

Assim, é cabível frisar que a flexibilização não é algo de todo ruim, pelo contrário, ela pode ser enxergada, também, como instituto possível e necessário pela óptica trabalhista, desde que seja implementada por meio de convenções ou acordos coletivos ou na forma que a lei determinar, sendo, necessariamente, observado o respeito à dignidade do ser humano. Caso não apresente esse requisito mínimo, como afirmou Cassar (2014, p. 83), tais acordos ou convenções devem ser taxados como inconstitucionais, uma vez que a dignidade humana é valor protegido por direitos fundamentais inseridos em âmbito constitucional.

É sob essa perspectiva que as mudanças alcançadas pelo adicional de insalubridade serão abordadas ao decorrer das próximas seções, sendo apontadas as alterações e consequentes contradições com os princípios ou dispositivos constitucionais que norteiam o ordenamento justrabalhista.

\subsection{INSALUBRIDADE E NEGOCIAÇÃO COLETIVA}

Já vimos que, conforme o art. 192 da CLT, o adicional de insalubridade pode ser de $10 \%, 20 \%$ ou $40 \%$, conforme seu enquadramento nos graus mínimo, médio ou máximo. Contudo, houve uma alteração no art. 611-A, inciso XII, estabelecendo que a convenção coletiva e o acordo coletivo de trabalho têm prevalência sobre a lei quando dispuserem sobre enquadramento do grau de insalubridade. A Medida Provisória no 808/2017 alterou o inciso XII do art. 611-A, determinando que a negociação coletiva respeitasse na integralidade as normas de saúde e as normas regulamentadoras do MTE (Ministério do Trabalho e Emprego), incluída a possibilidade de contratação de perícia, afastada a licença prévia das autoridades competentes do Ministério do Trabalho, desde que respeitadas, na integralidade, as normas de saúde, higiene e segurança do trabalho previstas em lei ou em 
normas regulamentadoras do Ministério do Trabalho. A Medida Provisória no 808/2017 teve seu prazo de vigência encerrado no dia 23 de abril do corrente ano.

Essa mudança gera a possibilidade de negociar o enquadramento do grau de insalubridade por negociação coletiva ou acordo coletivo de trabalho. 0 art. 611-A da Lei $\mathrm{n}^{\circ}$ 13.467/2017 incluiu nova disposição que estipula a prevalência das condições ajustadas mediante convenção ou acordo coletivo de trabalho, exemplificando em quinze incisos as matérias cuja disposição em negociação coletiva gozarão de supremacia em face da Lei. Com base no art. $2^{\circ}$ da Convenção 154 da Organização Internacional do Trabalho, negociação coletiva trata-se de um instrumento de composição de conflitos coletivos trabalhistas em que empregados e empregadores buscam superar conflitos de interesses com o objetivo de regular a relação entre eles, bem como celebrar contratos coletivos, convenções coletivas ou acordos coletivos, nos quais serão fixadas condições de trabalho. Pinto conceitua negociação coletiva da seguinte forma:

\footnotetext{
Entendida como o complexo de entendimentos entre representações de trabalhadores e empresas, ou suas representações, para estabelecer condições gerais de trabalho destinadas a regular as relações individuais entre seus integrantes ou solucionar outras questões que estejam perturbando a execução normal dos contratos. (1998, p. 68)
}

Em suma, trata-se de um processo que almeja a formalização da convenção ou do acordo coletivo de trabalho que obriga o conjunto de empregados de determinada empresa à observância das regras gerais resultantes da negociação coletiva. Ao observarmos o enquadramento do grau de insalubridade via negociação coletiva, sem os parâmetros técnicos que foram fixados pela Portaria $\mathrm{n}^{\circ} 3.214 / 1978$ e seus anexos, questionamo-nos se tais 
acordos e convenções são benéficos ou prejudiciais. 0 art. 190 da CLT estipulou que:

O Ministério do Trabalho aprovará o quadro das atividades e operações insalubres e adotará normas sobre os critérios de caracterização da insalubridade, os limites de tolerância aos agentes agressivos, meios de proteção e o tempo máximo de exposição do empregado a esses agentes.

Previu, ainda, que "As normas referidas neste artigo incluirão medidas de proteção do organismo do trabalhador nas operações que produzem aerodispersoides tóxicos, irritantes, alérgicos ou incômodos" (parágrafo único do mesmo artigo). Portanto, para ter validade, a negociação coletiva teria que aliar a previsão acerca do adicional devido com prova técnica que demonstre que tal adicional seja efetivamente adequado para afrontar o dano causado ao trabalhador. Do contrário, deveria ser observado o art. 192 da CLT:

O exercício de trabalho em condições insalubres, acima dos limites de tolerância estabelecidos pelo Ministério do Trabalho, assegura a percepção de adicional respectivamente de $40 \%$ (quarenta por cento), $20 \%$ (vinte por cento) e 10\% (dez por cento) do salário-mínimo da região, segundo se classifiquem nos graus máximo, médio e mínimo.

Nesse sentido, deveria também ser considerado o que foi previsto no art. 195, assegurando que "a caracterização e a classificação da insalubridade e da periculosidade, segundo as normas do Ministério do Trabalho, far-se-ão através de perícia a cargo de Médico do Trabalho ou Engenheiro do Trabalho, registrados no Ministério do Trabalho". Empregado e empregador estão envolvidos em uma relação desigual, porque o trabalhador sempre foi a parte vulnerável da relação entre capital e trabalho. Quando nos 
deparamos com essas alterações na lei, verificamos que permitir que o negociado nas normas coletivas prevaleça sobre o legislado indica uma possibilidade de redução de direitos. Por esse ponto de vista, a alteração pode ser negativa. Contudo, o art. 611-B, caput, aponta, taxativamente, as matérias cuja negociação coletiva não pode dispor, entre elas "adicional de remuneração para as atividades penosas, insalubres ou perigosas" (inciso XVIII), considerando como objeto ilícito do negócio jurídico coletivo que infringir a regra e, consequentemente, considerando nula a convenção e o acordo coletivo que reduzir ou suprimir tais direitos. 0 inciso XII do art. 611-A permite o enquadramento dos percentuais do adicional de insalubridade. 0 enquadramento não significa negação da existência da insalubridade. Repare que o art. 191 da CLT estabelece:

A eliminação ou a neutralização da insalubridade ocorrerá: I - com a adoção de medidas que conservem o ambiente de trabalho dentro dos limites de tolerância; ou II - com a utilização de equipamentos de proteção individual ao trabalhador, que diminuam a intensidade do agente agressivo a limites de tolerância.

Ao nos depararmos com o art. 611-B, inciso XVII, vimos que as normas de saúde, higiene e segurança do trabalho previstas em lei ou em normas regulamentadoras do Ministério do Trabalho não podem ser suprimidas ou sofrer redução de direitos mediante convenção coletiva ou acordo coletivo de trabalho. Entre as normas regulamentadoras de competência do Ministério do Trabalho e Emprego relativas a saúde e segurança no trabalho está a Norma Regulamentadora no 15, que trata de atividades e operações insalubres. Podemos concluir, portanto, que a redução do adicional de insalubridade constitui objeto ilícito de convenção coletiva ou de acordo coletivo de trabalho. 0 inciso XVIII do art. 
611-B aponta, de forma mais evidente, a ilicitude ao mencionar o adicional de insalubridade como um dos direitos que não podem sofrer redução mediante convenção coletiva ou acordo coletivo de trabalho.

Importa observar que o parágrafo único do art. 611-B menciona que regras sobre duração do trabalho e intervalos não são consideradas como normas de saúde, higiene e segurança do trabalho, ou seja, o legislador admite a possibilidade de supressão ou redução de duração de jornada de trabalho ou intervalos a partir de convenções ou acordos coletivos de trabalho, por considerar que tais direitos não constituem normas de saúde, higiene ou segurança do trabalho. Não admite, e nem poderia, entretanto, em relação ao adicional de insalubridade.

A Reforma Trabalhista, portanto, ampliou as matérias que podem ser negociadas mediante convenção ou acordo coletivo de trabalho. Contudo, ao analisarmos o art. 611-A, combinado com o art. 611-B, inciso XVIII, tendo por norte a regra de interpretação "in dubio, pro operario", observamos que a negociação coletiva, em caso de adicional de insalubridade, apenas deve prevalecer quando ampliativa dos direitos e vantagens já existentes, e não pode reduzir ou restringir os patamares mínimos conquistados. Segundo Almeida e Severo (2014, p. 27), a negociação coletiva é uma dimensão plural que permite o exercício mínimo de liberdade ao trabalhador, seja em âmbito individual, seja em âmbito, efetivamente, plural:

Ora, como modo de restituir ao trabalhador sua condição de sujeito livre, a negociação coletiva e a norma que daí resulta, não pode ter outro limite, que não aquele já estabelecido pelo ordenamento jurídico laboral. Do mesmo modo, não pode ter outra função que aquela de promover a melhoria das condições sociais dos trabalhadores que representa. 
Essa perspectiva abordada por Almeida e Severo sobre a razão de ser da negociação coletiva considera as divergências de interesses e desigualdade de poder inerentes às relações de trabalho. É por intermédio do exercício do poder empregatício que se instrumentaliza a subordinação jurídica no contexto da relação de emprego e, a partir dessa relação, a negociação coletiva mostra-se como a possibilidade do exercício mínimo de liberdade ao trabalhador. Nesse sentido, conforme os autores, o trabalhador recupera sua força enquanto classe social e, novamente, pode agir para pressionar o empregador a avançar em direção à sua proteção, garantindo as condições para que essa convivência continue existindo.

O Ministério Público do Trabalho (MPT) divulgou, em 04 de maio de 2017, a Nota Técnica $\mathrm{n}^{0} 6^{12}$, para expor seu posicionamento acerca do Projeto de Lei no 6.442/2016, que trata sobre a Reforma Trabalhista. A nota, assinada pelo Procurador-geral do Trabalho, Ronaldo Fleury, apontou violações à ordem constitucional e pugnou pela rejeição total da proposta. Diz o documento:

O objetivo da proposta contida no PL 6442/2016 é viabilizar a prevalência do negociado sobre o legislado independentemente do seu conteúdo. Assim, e considerando que o ordenamento brasileiro já prevê a prevalência do negociado sobre a lei sempre que a negociação significar criação de novo benefício ou a ampliação de benefício já previsto em lei, conclui-se que o único propósito do PL 6442/2016 é permitir a exclusão de direitos trabalhistas pela via negocial.

12 Disponível em: http://portal.mpt.mp.br/wps/wcm/connect/portal_mpt/ cd5575e1-7d3f-485b-92d0-4a0f5659cc0b/Nota+T\%C3\%A9cnica+06.2017+-+PL+6442-2016.pdf?MOD=AJPERES\&CVID=ISpSKYn . Acesso em: 26 set. 2018. 
Conforme a Nota Técnica, o projeto propõe redução de diversos direitos sociais por meio de acordos ou convenções. A Nota Técnica informa, ainda, que autorizar o rebaixamento de direitos por meio de negociação coletiva enfraquece as tratativas entre trabalhadores e empregadores, colocando em descrédito esse importante instrumento de pacificação dos conflitos coletivos de trabalho. 0 documento esclarece também que a realidade brasileira demonstra que existe um imenso desequilíbrio entre a representação dos trabalhadores e a representação patronal. Desequilíbrio, este, que sempre foi mitigado pela existência de direitos mínimos previstos em lei, à luz do princípio da proteção e aplicação da norma mais favorável.

O Ministério Público do Trabalho publicou também, em 09 de maio de 2017, a Nota Técnica no $7^{13}$. A Nota, assinada pelo Procurador-geral do Trabalho, Ronaldo Fleury, pediu um debate mais aprofundado sobre o tema, a rejeição parcial da proposta e sua adequação em alguns aspectos apontados no documento.

\begin{abstract}
[...] apesar de não permitir a prevalência do negociado sobre o legislado para reduzir ou suprimir direitos relacionados à segurança e à saúde do trabalhador, admite que o enquadramento da insalubridade e que a prorrogação de jornada em ambientes insalubres, atividades eminentemente técnicas, sejam fixadas por meio de negociação coletiva.
\end{abstract}

De acordo com a Nota Técnica, entre as inovações propostas no substitutivo em relação ao art. 611-A da CLT, cumpre ressaltar a inviabilidade da previsão de participação dos sindicatos como litisconsortes necessários em todos os processos em que discutida a nulidade de norma coletiva, pois, considerando o

13 Disponível em: http://portal.mpt.mp.br/wps/wcm/connect/portal_mpt/6e18cf0c-941b-437e-8557-f7554daae 5b4/notatecnica 07 . pdf?MOD=AJPERES\&CVID=INvhrzL. Acesso em: 26 set. 2018. 
efeito erga omnes dos acordos e convenções coletivas, torna-se impraticável que as entidades tenham que participar de inúmeras ações individuais (art. 611-A, § 5ํ), o que irá causar embaraço ao desenvolvimento normal de suas atividades.

A Nota Técnica informa que a prevalência do negociado sobre o legislado, nos termos propostos no PLC n³8/2017, não valoriza a negociação coletiva, mas cria espaços para a precarização das condições de trabalho ao permitir que sejam pactuados parâmetros laborais abaixo do que prevê a lei, gerando insegurança jurídica. É importante ressaltar que, embora existam preocupações quanto ao tema, o direito à negociação coletiva é sustentado por um campo principiológico. Dentro desse campo estão a autonomia privada coletiva, a vedação do retrocesso social e a melhoria da condição social do trabalhador. Portanto, o fundamental para que a negociação coletiva alcance o seu objetivo de solucionar conflitos em momentos de crise econômica é buscar o direito utilizando os instrumentos permitidos para encontrar o equilíbrio necessário nas relações de trabalho.

\subsection{INSALUBRIDADE GESTANTE/LACTANTE}

Em meados de 2016, foi sancionada e publicada a Lei $\mathrm{n}^{\circ}$ 13.287 $/ 2016^{14}$, acrescentando o art. 394-A a CLT. 0 art. 394-A dispunha o seguinte: "Art. 394-A. A empregada gestante ou lactante será afastada, enquanto durar a gestação e a lactação, de quaisquer atividades, operações ou locais insalubres, devendo exercer suas atividades em local salubre". Entendemos que o legislador incluiu o art. 394-A na CLT com o objetivo de proteger a saúde da mulher e, principalmente, do nascituro, durante os períodos de gestação e lactação, sabendo-se que as condições insalubres no ambiente de trabalho podem causar prejuízos também ao feto ou à criança. Estabeleceu o art. 394-A que competia às empresas,

14 Disponível em: http://www.planalto.gov.br/ccivil_03/_ato2015-2018/2016/ lei/L13287.htm. Acesso em: 08 out. 2018. 
de um modo geral, assegurar e garantir à gestante ou lactante, um ambiente de trabalho salubre, com o objetivo principal de garantia da saúde. Nesse contexto, compete ao empregador tomar as medidas cabíveis, visando afastar a trabalhadora gestante ou lactante do ambiente insalubre enquanto perdurar essa situação. Uma das modificações trazidas com a Reforma Trabalhista foi a alteração do art. 394, possibilitando à mulher grávida trabalhar em condição insalubre de grau mínimo ou médio, e à mulher que esteja amamentando trabalhar em local insalubre de qualquer grau, sendo necessário, para ser afastada, apresentar atestado médico. A própria Constituição Federal contém princípios protetivos ao trabalhador. Trata-se da lei mais alta, principal, o ideal de justiça do povo, que busca impedir excessos do poder político ou econômico. O que consta na Constituição é imprescindível, não podendo ser exigido o cumprimento de qualquer lei, decreto ou determinação de autoridade que contrarie os dispositivos constitucionais. Junto a outras leis, há leis trabalhistas que são regidas pela Constituição. Assim, na lei reformada, encontramos alguns aspectos questionáveis como, por exemplo, as alterações que flexibilizam a proibição de mulheres gestantes ou lactantes de exercerem atividade insalubre.

Ao fazermos uma análise desse movimento de alterações, algumas implicações surgem: essa mudança protege a quem? Quais são os interesses por trás dessas mudanças? Antes, a gestante não deveria exercer atividade em local insalubre; agora, ela pode. Só é impedida se exercer atividades consideradas insalubres em grau máximo ou se conseguir que algum médico a libere de exercer atividade em local prejudicial à sua saúde e, consequentemente, à saúde do feto. Sabemos que o médico avaliará sua paciente, não o local de trabalho, por isso, é questionado também se os atestados emitidos pelos médicos serão capazes de assegurar proteção para a mulher e para o feto. Sem examinar o local de trabalho e com conhecimento específico e necessário sobre segurança no 
trabalho insuficiente, esse profissional é incapaz de decidir quais condições são seguras e saudáveis para a mulher gestante.

Além disso, o trabalho de grávidas e lactantes em ambientes insalubres poderá afetar não apenas a trabalhadora, mas os recém-nascidos, mesmo antes do nascimento, por agentes contaminantes de adoecimento. 0 propósito do art. 394-A da CLT com a redação anterior foi assegurar proteção à gestante, à lactante, ao feto e à criança nos períodos de gestação e lactação, proibindo o trabalho da empregada em atividades, operações ou locais insalubres, que deveria, nesses períodos, exercer suas atividades em locais salubres, sem risco para ela e para o nascituro. Cassar (2017, p. 41) ressalta que, quando o local ou a função for prejudicial à grávida, ela deve ser afastada para exercer outra função; em caso de impossibilidade, será considerada gravidez de risco e, dessa forma, passará a receber o salário-maternidade, e o contrato de trabalho será suspenso. A Constituição Federal, em seus arts. 226 e 227, garante proteção integral à criança, devendo ser assegurado o seu melhor interesse, uma vez que a lactante está em período de nutrição de seu bebê.

Deve-se reconhecer a condição do nascituro como ser humano em desenvolvimento e, dessa forma, carecedor de proteção especial. Conforme Melo ${ }^{15}$, ao submeter a mulher grávida ou lactante a trabalhos em locais que as exponham a riscos, o aumento do nível de estresse é potencializado, gerando reflexos e consequências ao feto. Essas empregadas encontram-se temporariamente em condição excepcional, com necessidade de laborar em ambiente adequado e saudável, de modo a possibilitar que o bebê alcance o desenvolvimento satisfatório.

15 Disponível em: https://www.conjur.com.br/2017-jul-21/reflexoes-trabalhistas-reforma-erra-permitir-gravida-lactante-local-insalubre. Acesso em: 12 nov. 2018. 


\subsection{HONORÁRIOS PERICIAIS}

A Reforma Trabalhista alterou também o art. 790-B da CLT, que trata sobre o pagamento dos honorários periciais. Na Justiça do Trabalho, segundo a previsão do art. 195, § 3ำ da CLT, a caracterização e classificação de eventual exposição a insalubridade e periculosidade deverá ser feita por meio de perícia, a qual será realizada por Engenheiro do Trabalho nomeado pelo Juízo. Na Consolidação das Leis do Trabalho vigente, os honorários periciais poderão ser cobrados do reclamante, caso sucumbente no objeto da perícia, mesmo que este seja beneficiário da justiça gratuita, desde que tenha obtido, em juízo, créditos capazes de suportar referida despesa. Em caso negativo, tal encargo continuará a ser repassado à União. Na legislação anterior, por conta do disposto no art. 790-B da CLT, sempre entendeu-se que, em caso de sucumbência na pretensão objeto do pedido pela parte beneficiária da justiça gratuita, a União era a responsável pelo pagamento (Resolução n 66/2010 do CSJT ${ }^{16}$; Súmula n ${ }^{\circ} 457$, TST). ${ }^{17}$ No Processo do Trabalho, nunca se cobrou do beneficiário da justiça gratuita em momento posterior à sentença. A Lei $\mathrm{n}^{\circ} 13.467 / 2017$, por fim, trouxe questão intrigante em relação à obrigação do beneficiário da assistência judiciária gratuita de arcar com os custos da perícia, mesmo gozando de tal condição. Segundo o art. 790-B, em sua interpretação literal, foi excluída do benefício da gratuidade de Justiça a despesa atinente aos honorários periciais. É o que depreende o art. 790-B: "A responsabilidade pelo pagamento dos honorários periciais é da parte sucumbente

16 Disponível em: http://www.csjt.jus.br/c/document_library/get_ file?uuid=717d1c84-0b41-4fc0-b138-09cad3 720800\&groupId=955023. Acesso em: 02 nov. 2018.

17 "A União é responsável pelo pagamento dos honorários de perito quando a parte sucumbente no objeto da perícia for beneficiária da assistência judiciária gratuita, observado o procedimento disposto nos arts. 1ำ 2ำ e 5o da Resolução n. 66/2010 do Conselho Superior da Justiça do Trabalho - CSJT". Disponível em: http://www3.tst.jus.br/jurisprudencia/Sumulas_com_indice/ Sumulas_Ind_451_600.html\#SUM-457. Acesso em 02 nov. 2018. 
na pretensão objeto da perícia, ainda que beneficiária da justiça gratuita". Como podemos observar na leitura do artigo citado, segundo a redação do dispositivo inserido na CLT, o beneficiário da justiça gratuita, acaso sucumbente do objeto da perícia, responderá pelos encargos periciais. Diante da introdução do $\S 3^{0}$ do referido artigo, o juízo não poderá exigir adiantamento de valores para realização de perícia. Segundo Junior et al. (2018, p. 258), o legislador reformista perdeu a oportunidade de alinhar o regramento do tema àquele estabelecido no $\mathrm{CPC}$, que prevê expressamente a possibilidade da antecipação dos honorários periciais (CPC, arts. 95, caput, e S $1^{\circ}$, E 465, S $3^{\circ}$ ). Houve, ainda, a inclusão do $\S 4^{\circ}$ ao art. 790. Esse acréscimo prevê que somente no caso em que o beneficiário da justiça gratuita não tenha obtido em juízo créditos capazes de suportar a despesa, a União responderá pelo encargo. 0 parágrafo $4^{\circ}$ da CLT, agora contido no art. 790-B, decorrente da Lei ${ }^{\circ} 13.647 / 2017$, traz subjacente a noção de que será conferida ao perito a prerrogativa de ter os seus honorários deduzidos dos valores havidos nos autos. Contudo, o texto vai além, ao afirmar que a execução poderá abranger outros créditos, ainda que obtidos em processo diverso. Tal premissa leva-nos a crer que haverá a possibilidade de responsabilização da União, uma vez insuficiente a existência de crédito em face do devedor, ou seja, em todo caso, constatado pelo juízo que não existem recursos suficientes para o adimplemento da parcela, incumbirá à União a assunção do aludido encargo. Presume-se, assim, que serão ajustados os termos da Súmula 457 do TST, que estipula a obrigação de adimplemento sempre em desfavor da União:

SUM-457. HONORÁRIOS PERICIAIS. BENEFICIÁRIO DA JUSTIÇA GRATUITA. RESPONSABILIDADE DA UNIÃO PELO PAGAMENTO. RESOLUÇÃO № 66/2010 DO CSJT. OBSERVÂNCIA. A União é responsável pelo pagamento dos honorários de perito quando a parte sucumbente no objeto da perícia 
for beneficiária da assistência judiciária gratuita, observado o procedimento disposto nos arts. $1^{\circ}$, 2o e 5ำ da Resolução nำ 66/2010 do Conselho Superior da Justiça do Trabalho - CSJT.

É importante ressaltar que, pela expressão "obtido créditos" ( $\left(4^{\circ}\right.$, art. 790 da CLT), deve-se entender que a parte reclamante teve algum pedido julgado procedente, ainda que parcialmente, e a execução dessa condenação foi exitosa, com a efetiva percepção do valor pela parte exequente, ou seja, a exigibilidade da responsabilidade do obreiro beneficiário da justiça gratuita dependeria, pelo menos, da mudança da situação econômica do trabalhador, o que, por questões óbvias, somente poderia ocorrer em caso de um cumprimento de sentença exitoso em prol da parte reclamante. A União, ainda que responsável subsidiária, não é parte, logo, não pode sobre ela recair a responsabilidade pelo pagamento dos honorários periciais. Junior et al. (2018, p. 444) afirma que:

O que ocorrerá, sendo a parte sucumbente beneficiária da justiça gratuita, é que será exigível o pagamento imediato da verba honorária pela União, sem transfusão de responsabilidade, tanto que, sobrevindo alteração em sua fortuna pessoal, o beneficiário deverá restituir aos cofres federais o valor desembolsado para remuneração do perito.

Portanto, como a própria exigibilidade da responsabilização da parte reclamante fica vinculada à efetividade da execução contra a reclamada ou outra parte executada, é de se concluir que remanesce com a União o encargo de pagar os honorários periciais enquanto flui a execução trabalhista original da parte reclamante (ou em algum outro processo judicial). Nesse sentido, a União pagaria e ficaria sub-rogada nos direitos deste. Em seguida, o ente estatal, caso frutífera alguma execução judicial, poderia promover a execução contra a parte autora, visando que esta restituísse à 
União os honorários periciais já pagos. 0 prazo que a União teria para buscar a restituição do pagamento por meio da execução judicial seria de até cinco anos após o trânsito em julgado da constituição do crédito pericial, conforme o Código de Processo Civil (aplicação supletiva dos arts. 95, §§ 3o e 4º , e 98, § 3º , do Código de Processo Civil). Porém, conforme Junior et al. (2018, p. 446), o prazo da condição suspensiva de inexigibilidade, que era de cinco anos, foi reduzido, no processo do trabalho, para dois anos.

0 tema é latente, e trouxe consigo grande carga de polêmica. Não por menos, foi objeto de questionamento perante o STF na ação direta de inconstitucionalidade (ADI 5.766) ${ }^{18}$, de relatoria do Ministro Luis Roberto Barroso, ajuizada em 28 de agosto de 2017. Conforme descrito na Reforma Trabalhista Comentada por Juízes do Trabalho (LISBÔA; MUNHOZ, 2018, p. 371):

A inconstitucionalidade pretendida tem por fundamento básico a afirmada exigência de ônus desproporcionais para que cidadãos vulneráveis e desassistidos busquem o Judiciário, em violação aos arts. $1^{\circ}$, incs. III e IV; $3^{\circ}$, incs. I e III; 5ํㅜ, caput,

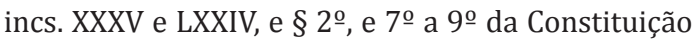
da República.

Apesar de haver questionamentos acerca da constitucionalidade da cobrança de honorários periciais daqueles beneficiários da justiça gratuita, ainda não houve qualquer alteração do art. 790-B da CLT.

\section{CONCLUSÃO}

O presente trabalho buscou analisar junto a entendimentos doutrinários as mudanças no adicional de insalubridade vindas com a reforma trabalhista. Como podemos ver, o entendimento

18 Disponível em: <http://portal.stf.jus.br/processos/detalhe. asp $i$ incidente=5250582 >. Acesso em: 07 nov. 2018. 
doutrinário orienta-se no sentido de proteger o trabalhador - a parte mais frágil na relação jurídica. A Reforma Trabalhista modificou elementos cruciais da relação de emprego, flexibilizando a proibição de mulheres gestantes ou lactantes de exercerem atividade insalubre e possibilitando a negociação do enquadramento do grau de insalubridade. Em outras palavras, ela constituiu um sistema que ampliou o poder e a liberdade do capital para determinar as condições de contratação.

No processo desta pesquisa, ao que nos parece, não há vantagens ao possibilitar o exercício de grávidas em local insalubre. Pelo contrário, essa flexibilização deixou a trabalhadora em uma condição de maior insegurança, vulnerabilidade e risco, possibilitando consequências negativas sobre sua vida familiar e social. Percebe-se que o legislador errou ao suprimir a garantia concedida às trabalhadoras gestantes em relação ao local de trabalho insalubre. A supressão de tais direitos não está protegendo o bem-estar e a saúde da gestante e do nascituro. Nem todos os atestados médicos, ou a ausência deles, são uma garantia de proteção à saúde da gestante, porque o médico pode não ter o conhecimento específico necessário sobre segurança no trabalho. Não temos garantia de que o médico irá até o local onde a mulher trabalha para ver as suas reais condições. O objetivo do art. 394A da CLT com a redação anterior foi de proteger a gestante e a lactante, o feto e a criança, nos períodos de gestação e lactação, proibindo o trabalho da empregada em atividades, operações ou locais insalubres, devendo, nesses períodos, exercer suas atividades em locais salubres, livres dos respectivos riscos. Se uma mulher grávida ou lactante, que trabalha em ambiente insalubre, mesmo com atestado médico, depois de certo período, comprovar a existência de prejuízo à saúde dela ou da criança, quais serão as consequências patronais em termos de responsabilidades civis, penais e demais agravos? Como se vê, a questão não é de simples solução, uma vez que envolve saúde e vidas humanas. Dessa for- 
ma, com a minimização da norma que permite à gestante exercer a atividade em locais insalubres, mesmo que em grau mínimo e médio, o legislador não protege a maternidade e os direitos dos infantes, direitos esses previstos na Constituição Federal.

Com relação à prevalência do negociado sobre o legislado, verifica-se que os incisos XII e XIII do art. 611-A da CLT permitem o enquadramento, via negociação coletiva, dos percentuais do adicional de insalubridade, com nítida pretensão de reduzi-los e, respectivamente, a prorrogação da jornada em atividade insalubre sem prévia autorização da autoridade competente, muito embora a insalubridade e seus graus sejam direitos relacionados à medicina e à segurança do trabalho, portanto, defeso à negociação coletiva nos termos do art. 611-B da CLT. Ao verificar essa nova disposição que estipula a prevalência das condições ajustadas mediante convenção ou acordo coletivo de trabalho, entendemos que a negociação do grau de insalubridade não poderá prever proteção inferior, conforme o art. 611-B, inciso XVIII, admitindo-se, apenas, a fixação de adicionais em percentuais mais elevados, em respeito ao caput e ao inciso XXII do art. 7ํ da Constituição, que garantem outros direitos que visem à melhoria da condição social dos trabalhadores e à redução dos riscos inerentes ao trabalho.

Com a Reforma da Consolidação das Leis do Trabalho, os honorários periciais passam a ser de responsabilidade do empregado, caso este não tenha êxito total na ação. Como pode ser observado, a alteração não estende mais o benefício da justiça gratuita em casos de a parte beneficiária ser sucumbente, devendo ela pagar o valor da perícia realizada. Visando enxugar os gastos da Justiça do Trabalho com perícias desnecessárias, percebemos que o referido artigo poderá dificultar o acesso do reclamante aos seus direitos em razão do seu trabalho. 0 trabalhador, pela própria essência do contrato de trabalho onde, em um dos polos, encontra-se o empregador com seu poder diretivo, organizacional e disciplinar e, no outro, o empregado, 
empenhando sua força de trabalho -, vê-se em posição de inferioridade. Portanto, verificasse a necessidade de que a legislação, por meio de mecanismos protetivos, iguale a posição de ambos. 0 objetivo não é acuar o empregador ao proteger seus empregados, mas apenas assegurar que ambos sejam igualmente amparados pelo Estado de Direito.

É visível o jogo de interesses que ensejou mudanças nas leis trabalhistas. Esse jogo segue a lógica de que, para alguém ganhar, outro precisa perder. Ceder parte da legislação trabalhista, que garante as condições mínimas para a compra da força de trabalho, é uma opção defendida para acelerar o crescimento econômico. Contudo, ao fazermos análise dos dispositivos alterados referente ao adicional de insalubridade, podemos concluir que seus efeitos podem ser nefastos em diferentes aspectos. Embora não se ignore que a legislação trabalhista deve acompanhar as novas realidades dos modelos produtivos, não menos certo é que as eventuais alterações não podem configurar ofensa aos direitos fundamentais sociais e ao princípio da proibição do retrocesso.

Ao observarmos as alterações nos dispositivos referentes ao adicional de insalubridade, prevendo prevalência do negociado sobre o legislado, permitindo que a empregada gestante ou lactante trabalhe em local insalubre (o que antes era totalmente vedado pela CLT) e submetendo o beneficiário da assistência judiciária gratuita a arcar com os custos da perícia, mesmo gozando de tal condição, podemos concluir que a Reforma Trabalhista fragilizou as relações de emprego. Evidencia-se, portanto, clara flexibilização incondicionada de desproteção dos direitos sociais, o que não é autorizado pelo ordenamento jurídico. Por isso, faz-se necessária a defesa e proteção dos direitos sociais, especialmente, quando eles tangenciam um direito individual, tal qual o afastamento da gestante que trabalha em local insalubre, entre os demais direitos anteriormente mencionados. Não é por menos que o jurista português J. J. Gomes Canotilho (1998, p. 336), ao tratar do 
"efeito cliquet" dos direitos humanos, afirma que eles não podem retroagir, podendo avançar somente na proteção dos indivíduos, ou seja, é inconstitucional qualquer tentativa tendente a revogar direitos sociais já regulamentados sem a elaboração de meios opcionais aptos a compensarem a aniquilação desses benefícios. Os direitos trabalhistas, nas esferas individual e coletiva, fazem parte dos direitos sociais e são, inegavelmente, direitos fundamentais. A legislação infraconstitucional, como é o caso da Lei $\mathrm{n}^{\circ} 13.467 / 2017$, evidentemente, deve respeitar as determinações hierarquicamente superiores, decorrentes do Direito Constitucional. Em matéria trabalhista, como mencionado, a Constituição da República determina a melhoria das condições sociais dos trabalhadores (art. 7ํㅗ caput), e não a piora do patamar de direitos dos empregados e da sua disciplina jurídica e legislativa. Fica nítida, assim, a determinação cogente de que os direitos trabalhistas, como direitos sociais, humanos e fundamentais, devem ser assegurados de forma progressiva, não admitindo-se retrocessos.

\section{REFERÊNCIAS}

ALMEIDA, A. E. de. As falácias (e a verdade) do programa de proteção ao emprego. Revista: Suplemento Trabalhista. v. 51, n. 135, p. 695-700. São Paulo: LTr, nov. 2015.

ALMEIDA, A. E. de.; SEVERO, V. S. Direito do trabalho: avesso da precarização. v.1. São Paulo: LTR, 2014.

BARRoS, Alice Monteiro de. Curso de Direito do Trabalho. 7.ed. São Paulo: LTR, 2011.

BRAGHINI, M. Reforma Trabalhista: flexibilização das normas sociais do trabalho. 2.ed. São Paulo: LTr, 2017.

BRASIL. ADI 5766. Ação direta de inconstitucionalidade. Lei ${ }^{\circ}$ 13.467/2017. Assistência judiciária gratuita. Disponível em: http:// portal.stf.jus.br/processos $/$ detalhe. asp $_{i}$ incidente $=5250582$. Acesso em: 07 nov. 2018.

BRASIL. Decreto no 93.413, de 15 de outubro de 1986. Promulga a Convenção no 148 sobre a Proteção dos Trabalhadores Contra os Riscos 
Profissionais Devidos à Contaminação do Ar, ao Ruído e às Vibrações no Local de Trabalho. Disponível em: http://www.planalto.gov.

br/ccivil_03/decreto/1980-1989/D93413.htm. Acesso em: 09 nov. 2018.

BRASIL. Decreto no 1.254, de 29 de setembro de 1994. Promulga a Convenção número 155, da Organização Internacional do Trabalho, sobre Segurança e Saúde dos Trabalhadores e o Meio Ambiente de Trabalho, concluída em Genebra, em 22 de junho de 1981. Disponível em:

http://www.planalto.gov.br/ccivil_03/decreto/1990-1994/D1254.htm. Acesso em: 29 ago. 2018.

BRASIL. Lei $\mathrm{n}$ - 185, de 14 de janeiro de 1936. Institui as comissões de salário mínimo. Disponível em: http://www2.camara.leg.br/legin/fed/ lei/1930-1939/lei-185-14-janeiro-1936-398024-publicacaooriginal-1-pl.html. Acesso em: 30 ago. 2018.

BRASIL. Lei no 13.287, de 11 de maio de 2016. Acrescenta dispositivo à Consolidação das Leis do Trabalho - CLT, aprovada pelo Decreto-Lei $n^{\circ} 5.452$, de $1^{\circ}$ de maio de 1943, para proibir o trabalho da gestante ou lactante em atividades, operações ou locais insalubres. Disponível em: http://www.planalto.gov.br/ccivil_03/_ato2015-2018/2016/lei/L13287. htm. Acesso em: 08 out. 2018.

BRASIL. Ministério Público do Trabalho. Nota Técnica no 06, de 04 de maio de 2017. Proposição: Projeto de Lei no 6442\2016. Institui normas reguladoras do trabalho rural e dá outras providências. Disponível em: http://portal.mpt.mp.br/wps/wcm/connect/portal_mpt/cd 5575e17d3f-485b-92d0-4a0f5659cc0b/Nota+T\%C3\%A9cnica+06.2017+-+PL+6442-2016. pdf?MOD=AJPERES\&CVID=ISpSKYn. Acesso em: 26 set. 2018.

BRASIL. Ministério Público do Trabalho. Nota Técnica no 07, de 09 de maio de 2017. Proposição: Projeto de Lei da Câmara no 38, de 2017. Altera a Consolidação das Leis do Trabalho - CLT, aprovada pelo Decreto-lei $n^{\circ}$ 5.452, de $1^{\circ}$ o de maio de 1943, e as Leis $n^{\circ}{ }^{\circ}$ 6.019, de 3 de janeiro de 1974, 8.036, de 11 de maio de 1990, e 8.212, de 24 de julho de 1991, a fim de adequar a legislação às novas relações de trabalho. Disponível em: http://portal.mpt.mp.br/wps/wcm/connect/portal_mpt/6e18cf0c-941b-437e-8557-f7554daae 5b4/notatecnica07. pdf?MOD=AJPERES\&CVID=lNvhrzL. Acesso em: 26 set. 2018. 
BRASIL. Resolução no 66, de 10 de junho de 2010. Regulamenta, no âmbito da Justiça do Trabalho de primeiro e segundo graus, a responsabilidade pelo pagamento e antecipação de honorários do perito, do tradutor e do intérprete, no caso de concessão à parte do benefício de justiça gratuita. Disponível em: http://www.csjt.jus.br/c/document_library/get_ file?uuid=717d1c84-0b41-4fc0-b138-09 cad3720800\&groupId=955023. Acesso em: 02 nov. 2018.

BRASIL. Supremo Tribunal Federal. Súmula Vinculante $n^{\circ} 4$. Salvo nos casos previstos na Constituição, o salário mínimo não pode ser usado como indexador de base de cálculo de vantagem de servidor público ou de empregado, nem ser substituído por decisão judicial. 30 abr. 2008. Disponível em: http://www.stf.jus.br/portal/cms/verTexto.asp?servico=jurispruden ciaSumulaVinculant e\&pagina=sumula_001_016. Acesso em: 22 ago. 2018.

BRASIL. Tribunal Superior do Trabalho. Súmula $\mathrm{n}^{\circ}$ 17. Adicional de insalubridade (cancelada na sessão do Tribunal Pleno realizada em 26 jun. 2008). Res. 148/2008, DJ 04 e 07 jul. 2008. Republicada DJ 08, 09 e 10 jul. 2008. $O$ adicional de insalubridade devido à empregado que, por força de lei, convenção coletiva ou sentença normativa, percebe salário profissional será sobre este calculado. Disponível em: http://www3. tst.jus.br/jurisprudencia/Sumulas_com_indice/Sumulas_Ind_1_50. html\#SUM-17. Acesso em: 22 ago. 2018.

BRASIL. Tribunal Superior do Trabalho. Súmula $\mathrm{n}^{\circ}$ 80. Diário de Justiça. Brasília, 19, 20 e 21 nov. 2003. INSALUBRIDADE (mantida) - Res. 121/2003, DJ 19, 20 e 21 nov. 2003. A eliminação da insalubridade mediante fornecimento de aparelhos protetores aprovados pelo órgão competente do Poder Executivo exclui a percepção do respectivo adicional. Disponível em: http://www3. tst.jus.br/jurisprudencia/Sumulas_com_indice/Sumulas_Ind_51_100. html\#SUM-80. Acesso em 23 ago. 2018.

BRASIL. Tribunal Superior do Trabalho. Súmula n 228 . Adicional de Insalubridade. Base de Cálculo (redação alterada na sessão do Tribunal Pleno em 26 jun. 2008). Res. 148/2008, DJ 04 e 07 jul. 2008. Republicada DJ 08, 09 e 10 jul. 2008. Súmula cuja eficácia está suspensa por decisão liminar do supremo tribunal federal. Res. 185/2012, DEJT divulgado em 25, 26 e 27 set. 2012. A partir de 09 de maio de 2008, data da publicação da Súmula Vinculante no 4, do Supremo Tribunal Federal, o adicional de insalubridade será calculado sobre o salário básico, salvo critério mais vantajoso fixado em instrumento coletivo. Disponível em: 
http://www3.tst.jus.br/jurisprudencia/Sumulas_com_indice/Sumulas_Ind_201_250.html\#SUM-228. Acesso em 23 ago. 2018.

BRASIL. Tribunal Superior do Trabalho. Súmula $n^{\circ}$ 248. Diário de Justiça, Brasília, 19, 20 e 21 nov. 2003. Adicional de insalubridade. Direito adquirido (mantida). Res. 121/2003, DJ 19, 20 e 21 nov. 2003. A reclassificação ou a descaracterização da insalubridade, por ato da autoridade competente, repercute na satisfação do respectivo adicional, sem ofensa a direito adquirido ou ao princípio da irredutibilidade salarial. Disponível em: http://www3.tst.jus.br/jurisprudencia/Sumulas_com_indice/ Sumulas_Ind_201_250.html\#SUM-248. Acesso em: 23 ago. 2018.

BRASIL. Tribunal Superior do Trabalho. Súmula n 289. Diário de Justiça. Brasília, 19, 20 e 21 nov. 2003. Insalubridade. Adicional. Fornecimento do aparelho de proteção. Efeito (mantida). Res. 121/2003, DJ 19, 20 e 21 nov. 2003. $O$ simples fornecimento do aparelho de proteção pelo empregador não o exime do pagamento do adicional de insalubridade. Cabe-lhe tomar as medidas que conduzam à diminuição ou eliminação da nocividade, entre as quais as relativas ao uso efetivo do equipamento pelo empregado. Disponível em: http://www3.tst.jus.br/jurisprudencia/ Sumulas_com_indice/Sumulas_Ind_251_300.html\#SUM-289. Acesso em: 23 ago. 2018.

BRASIL. Tribunal Superior do Trabalho. Súmula no 457 do TST. Honorários Periciais. Beneficiário da Justiça Gratuita. Responsabilidade da união pelo pagamento. Resolução nº 66/2010 DO CSJT. Observância. (Conversão da Orientação Jurisprudencial no 387 da SBDI-1 com nova redação). Res. 194/2014, DEJT. Divulgado em 21, 22 e 23 mai. 2014. A União é responsável pelo pagamento dos honorários de perito quando a parte sucumbente no objeto da perícia for beneficiária da assistência judiciária gratuita, observado o procedimento disposto nos arts. $1^{\circ}, 2^{\circ}$ e 5o da Resolução n.o 66/2010 do Conselho Superior da Justiça do Trabalho - CSJT. Disponível em: http://www3.tst.jus.br/jurisprudencia/ Sumulas_com_indice/Sumulas_Ind_451_600.html\#SUM-457. Acesso em: 02 nov. 2018.

CANOTILHO, J. J. G. Constitucional e teoria da constituição. 3.ed. Coimbra: [s.n.], 1998.

CASSAR, V. B. Direito do Trabalho. 9.ed. São Paulo: Método, 2014.

CASSAR, V. B. Gestante e lactante em trabalho insalubre: art. 394-A da CLT. In: Comentários à reforma trabalhista. São Paulo: Método, 2017. 
DELGADO, M. G. Curso de direito do trabalho. 11.ed. São Paulo: LTr, 2011. DIÁLOGO e responsabilidade provocam avanço "extraordinário" na legislação. Planalto, 2018. Disponível em: http://www2.planalto.gov.br/ acompanhe-planalto/noticias/2017/07/dialogo-e-responsabilidade-provocam-avanco-extraordinario-na-legislacao. Acesso em: 12 out. 2018.

GOMES, O.; GOTTSCHALK, E. Curso de Direito de Trabalho. Rio de Janeiro: Forense, 2006.

JÚNIOR, A. U. de S.; SOUZA, F. C. de.; MARANHÃO, N.; NETO, P. T. de A. Reforma Trabalhista: análise comparativa e crítica da Lei no 13.467/2017 e da Med. Prov. no 808/2017. 2.ed. São Paulo: Rideel, 2018.

LISBÔA, D.; MUNHOZ, J. L. (Org.) Reforma Trabalhista: comentada por juízes do trabalho: artigo por artigo. São Paulo: LTr, 2018.

MAIOR, J. L. S. Em defesa da ampliação da competência da Justiça do Trabalho. Revista, São Paulo, jan. 2006. Disponível em: https://juslaboris.tst. jus.br/bitstream/handle/20.500.12178/105324/2005_maior_jorge_defesa_ampliacao.pdf?sequence=1\&isAllowed=y. Acesso em: 20 set. 2018.

MARTINS, S. P. Curso de Direito do Trabalho. 5.ed. São Paulo: Dialética, 2009.

MEIRELLES, P. de. Uma análise do adicional de insalubridade a partir dos princípios da proteção ao trabalhador e da dignidade da pessoa humana. 2011. 82 f. Monografia (Bacharelado) - Programa de Graduação em Direito, Universidade Federal do Rio Grande do Sul, Porto Alegre, 2011.

MELO, R. S. de. Reforma erra ao permitir atuação de grávida e lactante em local insalubre. Conjur, 2017. Disponível em: https://www.conjur. com.br/2017-jul-21/reflexoes-trabalhistas-reforma-erra-permitir-gravida-lactante-local-insalubre. Acesso em: 12 nov. 2018.

MESTIERI, N. Adicional de periculosidade e adicional de insalubridade. Disponível em: http://nilzamestieri.jusbrasil.com.br/artigos/112358312/adicional-de-periculosidade-e-adicional-deinsalubridade. Acesso em: 31 de agosto de 2018.

MIRANDA, C. A. Introdução à saúde no trabalho. São Paulo: Atheneu, 1998.

MORAES, E. de. Os acidentes de trabalho e sua reparação. São Paulo: LTr, 2009.

NASCIMENTO, A. M. Curso de Direito do Trabalho: história e teoria geral do direito do trabalho: relações individuais e coletivas do trabalho. 19.ed. São Paulo: Saraiva, 2004. 
NASCIMENTO, A. M. Iniciação ao direito do trabalho. 32.ed. São Paulo: LTr, 2006.

NETO, M. J. e. S. Curso de Direito Constitucional. Rio de Janeiro: Lúmen Juris, 2006.

PASTORE, J. Relações de trabalho em uma economia que se abre. Revista LTr. São Paulo, n. 1, 1995.

PINTO, J. A. R. Direito Sindical e Coletivo do Trabalho. São Paulo: LTr, 1998.

RODRIGUEZ, A. P. Los princípios del derecho del trabajo. 2.ed. Buenos Aires: Depalma, 1990.

SCARLET, I. W. A eficácia dos direitos fundamentais. 5.ed. Porto Alegre: Livraria do Advogado, 2003.

. Direitos fundamentais sociais e proibição de retrocesso: algumas notas sobre o desafio da sobrevivência dos direitos sociais num contexto de crise. Revista: Instituto de Hermenêutica Jurídica. Porto Alegre, n. 2, 2004.

SOUZA, R. T. de. (Org.): AMARAL, M. L. do.; JUNIOR, R. F. C. dos S.; SEREVO, V. S. (Coordenadores). CLT Comentada pelos Juízes do Trabalho da 4⿳亠丷a Região. 2.ed. São Paulo: LTR, 2017.

SILVA, D. P. Dicionário Jurídico. 16.ed. Rio de Janeiro: Forense, 1999.

SILVA, J. A. da. Curso de Direito Constitucional Positivo. 27.ed. São Paulo: Malheiros Meditadores, 2006.

SÜSSEKIND, A. Curso de Direito do Trabalho. 2.ed. Rio de Janeiro: Renovar, 2004. 